DR SEAN JAMES MONAGHAN (Orcid ID : 0000-0002-7692-7756)

Article type : Commissioned Review or Article

Corresponding author mail id: s.j.monaghan@stir.ac.uk

\title{
Salmon immunological defense and interplay with the modulatory capabilities of its ectoparasite Lepeophtheirus salmonis
}

Running title: Immunomodulation by the salmon louse

Laura M Braden ${ }^{1,3}$, *Sean J Monaghan², Mark D Fast ${ }^{3}$

${ }^{1}$ AquaBounty Canada, Bay Fortune, PEI, Canada

2Institute of Aquaculture, University of Stirling, Stirling, UK

${ }^{3}$ Department of Pathology \& Microbiology, Atlantic Veterinary College-UPEI, Charlottetown, PEI, Canada

\section{Conflict of Interest}

The authors declare there is no conflict of interest.

\section{Data Availability}

$\mathrm{n} / \mathrm{a}$

\section{Author Contributions}

All authors contributed equally to this work.

This article has been accepted for publication and undergone full peer review but has not been through the copyediting, typesetting, pagination and proofreading process, which may lead to differences between this version and the Version of Record. Please cite this article as doi: 10.1111/PIM.12731

This article is protected by copyright. All rights reserved 


\section{Abstract}

The salmon louse Lepeophtheirus salmonis (Lsal) is an ectoparasitic copepod that exerts immunomodulatory and physiological effects on its host Atlantic salmon. Over 30 years of research on louse biology, control, host responses and the host-parasite relationship has provided a plethora of information on the intricacies of host resistance and parasite adaptation. Atlantic salmon exhibit temporal and spatial impairment of the immune system and wound healing ability during infection. This immunosuppression may render Atlantic salmon less tolerant to stress and other confounders associated with current management strategies. Contrasting susceptibility of salmonid hosts exists and early pro-inflammatory Th1 type responses are associated with resistance. Rapid cellular responses to larvae appear to tip the balance of the host-parasite relationship in favour of the host, preventing severe immune-physiological impacts of the more invasive adults. Immunological, transcriptomic, genomic and proteomic evidence suggests pathological impacts occur in susceptible hosts through modulation of host immunity and physiology via pharmacologically active molecules. Coevolutionary and farming selection pressures may have incurred preference of Atlantic salmon as a host for $L s a l$ reflected in their interactome. Here we review host-parasite interactions at the primary attachment/feeding site, and the complex life-stage dependent molecular mechanisms employed to subvert host physiology and immune responses.

Keywords: Salmon lice, immunomodulation, virulence, aquaculture, Atlantic salmon, host-parasite relationship

This article is protected by copyright. All rights reserved 


\section{Introduction}

Commercial production of Atlantic salmon continues to expand in order to supply increasing consumer demands in emerging markets of the global aquaculture industry. Growth is estimated to exceed $8 \%$ per annum (1). However, intensive farming is associated with challenges, including bacterial, viral, fungal and parasitic diseases. Of these, ectoparasitic salmon lice Lepeophtheirus salmonis ( $\mathrm{Lsal}$ ) are the chief disease constraint to Atlantic salmon aquaculture sustainability in the Northern hemisphere, costing the industry an estimated $>\$ 874 \mathrm{M}$ US (£700M) per annum to control (2). Full costs to the industry in terms of productivity are considerably higher due to impaired growth, increased feed input, and downgrading of harvested fish (3). Furthermore, indirect costs such as coinfections with viral and bacterial pathogens and environmental impact of lice and treatments contribute signficantly to negative consumer perception of the industry (4).

It is well reported from both field and lab-based studies that salmon lice prevalence and intensity vary significantly between salmonid species. Atlantic salmon (Salmo salar L.) exhibits a highly susceptible phenotype $(5,6)$. The mechanisms governing these differences and the adverse impacts incurred to susceptible hosts such as $S$. salar has received increasing attention over the last 30 years. Histopathological comparisons of localised infections in salmonids (7-9) inferred weaker inflammation and tissue proliferation were characteristics of Atlantic salmon susceptibility. Contrasting data on salmonid species-specific immunological and mucosal responsiveness to Lsal (10-14) suggested some association of these responses with louse-induced modulation. The evolution of molecular 'omics' analytical tools has enabled further in-depth understanding of the immunological (reviewed in (15)) and physiological changes previously described (reviewed in (16)) that occur during the course of infection. Filling knowledge gaps on parasitic mechanisms impairing the host health is important for understanding the impacts of implementing appropriate integrated pest management control strategies to reduce $L s a l$ infections whilst maintaining host welfare.

Thus, the purpose of the present review was to summarize the current body of literature pertaining to the host-parasite relationship of Lsal and Atlantic salmon, taking note of potential complications of lice management, with a particular focus on the molecular interactions involved in successful parasitism by subverting host immunity and physiology. The co-evolutionary pressure for Lsal infection on S. salar is discussed in this context.

This article is protected by copyright. All rights reserved 


\section{Infection and Host Response}

Lepeophtheirus salmonis (Krøyer, 1837) is an ectoparastic copepod of the family Caligidae that infects the skin of salmonid fish (Figure 1A). The direct life cycle of Lsal includes five larval stages: two planktonic naupliar stages, one copepodite stage, and two chalimus stages $(17,18)$. The infectious free-swimming copepodite uses mechanical, chemical, and visual cues for attaching to a host $(19,20)$. Ionotropic receptors on the first antenna enables settlement on a suitable salmonid host facilitated by chemotaxis to host semiochemical cues (21-24). There are three post-larval stages: two sexed preadult stages and one sexed male and female adult stage (Figure 1). The primary attachment of the copepodite to the salmon is achieved by embedding modified secondary antennae into the skin epithelium. Secondary attachment follows by the formation of a frontal filament and a moult to the first chalimus stage (Chalimus I) $(25,26)$. The filament is used to anchor the louse to the host; however, despite the penetration in host epidermis there is rarely evidence of a host response at this primary attachment site (8,26,27)(Figure 1B), with inflammation and epithelial hyperplasia restricted to the periphery of the attachment/feeding site in Atlantic salmon $(7,8,15)$. For a broad description of the biology and lifecycle of $L$ sal the reader is referred to several comprehensive reviews $(16,28,29)$.

During the permanently attached chalimus stages (Chalimus I and II) the parasite grows between moults (18), but only feeds within the vicinity of the attachment site prior to moulting into a mobile pre-adult. Thus, erosion inflicted by the sessile chalimus stages to the fish epidermis is far more limited (sometimes characterised by localised melanised spots (5)) than later mobile stages, and juvenile parasites are less commonly found to have blood in their gut contents, feeding predominantly on mucus and skin epithelium (30,31). In contrast, mobile pre-adult and adult stages have much greater haemotophageous feeding activity whereby the gut is often filled with blood (Figure 1A) and this stage of parasitism is associated with significant mechanical induced epithelial damage associated with grazing and intense inflammation. High pre-adult and adult lice burdens often result in degradation of the skin to underlying tissues resulting in bleeding wounds $(3,9)$. The greater physical impact associated with these much larger aggressive feeding stages results in physiological disruption of Atlantic salmon through increased plasma cortisol, elevated plasma chloride, increased haematocrit and electrolyte levels and altered osmoregulatory capacity $(5,6,32)$.

This article is protected by copyright. All rights reserved 
Behavioural responses exhibited by Atlantic salmon during experimental infection include significant flashing and jumping immediately following exposure to larval Lsal (5). An initial inflammatory response occurs upon attachment of copepodite/first chalimus (e.g. within 3 dpi) characterised by transcriptional pro-inflammatory mediator activity (e.g., interleukin (il) $1 \beta$, illR, il12, tumour necrosis factor $\alpha$, prostaglandin $\left.E_{2}\right)$ and T cell activity $(c d 4 / c d 8)(33,34)$. A biphasic immune response is associated with the moult from copepodite to developing chalimus whereby many immune genes are downregulated from 1-5 days post-attachment (infection; (dpi)) then subsequently upregulated to near control levels by day $10 \mathrm{dpi}(35,36)$. The transition to chalimus is accompanied by transcriptomic changes in the host response (15,33-35). However, this response is followed by the down-regulation of genes throughout chalimus development, the degree of which is influenced by infection intensity (37), before a second innate inflammatory spike occurs $(33,34)$. Although susceptible fish are relatively unresponsive histologically to attached chalimus stages (i.e. at the attachment point and feeding site by the mouth tube (Figure 1B)), epithelial cell migration, fibrosis and macrophage infiltration has been reported in Atlantic salmon associated with remnants of a frontal filament in the absence of a live chalimus (7).

It has been suggested that $\mathrm{T}_{\mathrm{h}} 1$ and $\mathrm{T}_{\mathrm{h}} 17$ type responses (e.g. IFN, CD8 $\alpha$, IL-17) could play a role in resistance of salmonids during these early (chalimus) infection stages as the expression of transcripts associated with these pathways have been shown in multiple studies to negatively correlate with larval louse burden in Atlantic salmon (36,37). An era of genomic and transcriptomic research on selective breeding for more resistant Atlantic salmon families has provided vital information on potentially protective immune responses to juvenile sea lice stages using transcriptomic profiling (3640). For example, differences in susceptibility have been reported between strains and families of Atlantic salmon, including between wild and farmed populations (41), initiating selective breeding programs for these resistant traits. To date, only moderate genetic variation has been detected in resistance to Lsal in Atlantic salmon $(42,43)$. However, by analysing quantitative trait loci (QTL) in Atlantic salmon 'less susceptible' to another sea louse species, Caligus rogercresseyi (Crog), 7 and $13 \%$ heritability was accounted for by three QTLs (39). One of the genes transducer of erbB-2 1 (tobl) located on chromosome 3 of Atlantic salmon is a transcription factor that negatively regulates cell proliferation, specifically T lymphocytes (44), and exhibits significantly lower expression in skin

This article is protected by copyright. All rights reserved 
with attached chalimus (39). Differential expression of many T lymphocyte-associated genes during Lsal infection supports the role of these cells in the host response, as reported in a number of studies (34,35,37,45-47). Interestingly, overexpression of tob1 has been described during the response of

very small juvenile pink salmon prior to achieving natural resistance $(0.3 \mathrm{~g}$; ((48)), further supporting the role of T lymphocytes in the host response to Lsal.

The moult to pre-adult is accompanied by decreased systematic monocyte/macrophage activity, such as reduced respiratory burst and phagocytosis $(49,50)$. Coincidentally, there is significant overexpression of localized innate inflammatory mediators (e.g., ill $\beta$, il $8, \operatorname{tnf} \alpha ;(46,51))$, prostaglandin synthetases, and metalloproteinases ( linked with minimal transcript activity associated with cellular proliferation $(34,46,52)$. Expression of matrix metalloproteinases are controlled by specific signaling pathways including pro-inflammatory cytokines and are largely responsible for the degradation and remodelling of extracellular matrix (ECM) components (53), and thus play a vital role in wound healing (54). However, dysregulation of MMPs contributes to chronic wounds, a hallmark feature of susceptibility to Lsal $(12,33,45,46,51)$. Regulatory $\mathrm{T}_{\mathrm{h}} 2$ type responses could potentially be associated with protection vis a vis increased production of immunoglobulins and TGF- $\beta$-mediated tissue repair $(36,46)$. However, these responses (i.e. arginase-1, il10, $\operatorname{tg} f \beta$, and alternative macrophage activation) appear delayed in Atlantic salmon (46), and are not associated with reduced lice numbers (34,52). Although antigen presentation does not appear highly activated (i.e., $\mathrm{MH}$ class $\mathrm{II}^{+}$cells) in response to $\mathrm{Lsal}(36,46)$, immunoglobulin transcripts (igm and igt) are significantly upregulated in both skin and spleen of early stage infected Atlantic salmon (34,35). Furthermore, greater levels of immunoglobulin mRNA have been demonstrated by at least one study to be associated with typical areas of skin at salmon lice attachment sites (36). Serum antibodies (IgM) from Lsal-infected salmon recognise Lsal antigen, but their protective capacity has not been demonstrated as evidence of adaptive immunity to Lsal is lacking $(15,33,55,56)$.

\section{Management and Intervention}

An inability to make substantive gains in host resistance to lice through genetic selection, coupled with minor advances in ectoparasite vaccinology (42,43,57-60), and significantly lower relative 
protection afforded by anti-louse functional feeds (61), has left the salmon farming industry with chemotherapeutic intervention as the main option for louse control. Decreases in lice abundance in the mid-90's were attributed to the use of azamethiphos in Canada (62), whereas use of organophosphates in Norway, dating back to the late 1970's, was associated with reduced efficacy leading to its termination by 1999 . In 2000 , emamectin benzoate sold under the trade name SLICE ${ }^{\circledR}$ as an in-feed treatment became available to farmers and was used extensively in the North Atlantic. Lees et al. (63) was the first to report reduced efficacy of SLICE ${ }^{\circledR}$ treatments in Scotland, showing longer times to achieve efficacy and post-treatment counts increasing from 2003 to 2006 . Treatment failures were observed in Atlantic Canada and Norway in 2008 (64). Despite increasing reports of resistance of lice to current chemotherapeutants (64), the use of medicinal treatments has increased in every country with the exception of Norway $(4,65)$.

With the development of resistance to available chemotherapeutants, an integrated pest management strategy has been introduced that involves a number of pharmaceutical, mechanical and biological control methods (reviewed in $(2,66)$ ). For example, prevention strategies focus on keeping the infective copepodites away from host fish (67), either by attracting the fish to depths using lights or underwater feeding (68), by physical obstruction at the top part of the cage (e.g., snorkel cages; (69)) or by keeping copepodites out of the cage using plankton skirts (70). Removal of existing lice infections can be accomplished by the use of cleaner fish (lumpfish and wrasse) that feed mainly on the larger stages of lice from the surface of the fish (71). The use of these methods is relatively recent and under continuous development to improve efficacy and reduce negative impacts on the host (72). For example, cohabitating fish inevitably enhances sources of viral and bacterial disease transmission, some of which may be notifiable (73), potentially threatening already immunocompromised hosts (74). Furthermore, treatment-induced stress may result in an enhanced susceptibility to Lsal infections, which further impairs immune-responsiveness to the parasite $(33,52)$. Prolonged exposures to such stressors may result in a prolonged state of allostasis (i.e. physiological adaptation to stress leading to the release of catecholamines and glucocorticoids in an attempt to restore homeostasis), which in $S$. salar impairs leukocyte activity to bacterial antigen (16). This might ultimately render treated salmon more susceptible to microbial infections and less responsive to vaccination (75). Finally, there is a concern that the development of resistance to medicinal treatments will negatively 
impact both farmed and wild fish stocks (64). This has become apparent even for environmentally sound treatments with reduced effectiveness of $\mathrm{H}_{2} \mathrm{O}_{2}(76)$, high tolerance of sea lice to freshwater treatment $(77,78)$, and selecting for increased virulence through management practices (79).

\section{Host Specificity}

The salmon louse principally infects anadromous salmonids of the genera Salmo, Oncorhynchus, and Salvelinus $(8,29,80)$; however, among juvenile members of these genera, there is a spectrum of susceptibility whereby certain species (e.g., Atlantic salmon) are more prone to the pathological effects of infestation such as epithelial degradation, tissue necrosis, altered mucosal biochemistry, enhanced susceptibility to secondary infections, anaemia, elevated plasma cortisol, osmoregulatory failure, and sometimes death $((5,16,49,81,82)$; Figure 2$)$. In contrast, juveniles of other species such as pink salmon (O. gorbuscha) are protected from these negative outcomes due to an enhanced ability to reject the parasite. For example, laboratory experiments exposing pink salmon to Lsal has shown that at approximately $0.7 \mathrm{~g}$, juveniles develop the ability to rapidly reject the parasite, despite infection pressures exceeding 75 copepodites per fish $(48,83)$, and this natural resistance occurs despite inadequate nutrition (84). Similarly, juvenile coho salmon (O. kisutch) are able to reduce parasite load from $\sim 40$ to $<1$ lice per fish after only 18 dpi (L. Braden, pers obs; (27)). Inflammatory cell infiltration and hyperplastic tissue encapsulation of the copepodite has been described during the process of parasite elimination $(8,86)$. In common garden experimental challenges, Sutherland et al. observed preferential infection of chum and Atlantic salmon over pink salmon (45). In contrast, experimental challenges comparing host responses in sockeye salmon (O. nerka) and Atlantic salmon indicate that sockeye are much more susceptible to infection and pathology associated with infection of Lsal (85). Chalimus survival after experimental exposure was higher on juvenile chum salmon $(O$. keta) compared to pink salmon (86), while comparative studies between Atlantic salmon and sea trout (Salmo trutta) indicate that the latter was more susceptible (87). Moreover, although Atlantic salmon are highly susceptible to infection, intraspecific heterogeneity in susceptibility occurs among distinct spawning stocks $(41)$, and within full-sib families $(59,88)$. Interestingly, fitness of the parasite appears to negatively correlate with resistance status, as development time from copepodite to pre-adult is shorter while parasitizing Atlantic salmon compared to rainbow trout or coho salmon (49). Although

This article is protected by copyright. All rights reserved 
these variable susceptibilities are observed experimentally among juvenile salmonids (i.e., single infection), it is important to consider that these might not fully encompass infection dynamics in the field (i.e., continuous exposure) or life history and energetic demands of the host. For example, migrating pink salmon are observed to harbour large numbers of parasites in the open ocean (89) and laboratory experiments have revealed a divergent immune response to Lsal in sexually maturing adults compared to juveniles with several biomarkers of resistance (e.g., the number of MHII $\beta^{+}$cells) downregulated in adults (90). In contrast, coho salmon routinely exhibit the lowest prevalence of Lsal in field assessments (91) suggesting that resistance is maintained throughout development.

Notwithstanding, the lack of an inflammatory response to anchored Lsal chalimii in certain salmonids is strongly correlated with susceptibility (8), and this has been shown to be a product of louse-induced immunosuppression (12).

\section{Host Defense Mechanisms}

Enhanced resistance to infection has been correlated with rapid and robust inflammatory and acute phase immune responses in skin that are paired with a regulatory $\mathrm{T}_{\mathrm{h}} 2$-type response, infiltration of antigen presentation cells (MHII $\beta^{+}$cells) and wound repair, whereas these tend to be delayed or weakened in more susceptible species $(45,46,48,51,83,86,92)$. Iron metabolic pathways are also affected by Lsal infection in a species-dependent manner along with blood haematocrit and anaemia. For example, transcriptomic data on pink salmon indicates that an element of nutritional immunity (i.e. sequestration of nutrients from pathogens during infection) over chum salmon and Atlantic salmon may be associated with greater resistance of the former (45). Experiments with primary cell preparations has demonstrated a general immunomodulatory effect of $L s a l$ excretory/secretory (ES) products and this appears to correlate with resistance status. For example, Lewis et al. exposed primary cells from salmon anterior kidneys to concentrated Lsal ES proteins and found that macrophages isolated from pink salmon possessed the highest phagocytic and respiratory burst activities towards Aeromonas salmonicida spp. salmonicida cells compared to either chum (O. keta) or Atlantic salmon (93). In contrast, macrophages isolated from Lsal-infected rainbow trout ( $O$. mykiss) and Atlantic salmon have displayed reduced phagocytic ability and respiratory burst $(49,50)$. Furthermore, Fast et al. measured a demonstrable decrease in expression of proinflammatory cytokine 
ill $\beta$ in Atlantic salmon head-kidney macrophages and SHK-1 cells after exposure to fractionated ES products (12).

Research indicates that the weakened host defenses described in susceptible species may be a response to parasite secretions produced during feeding. For example, skin mucus from coho salmon does not stimulate the same magnitude of ES product release from L. salmonis as compared to Atlantic salmon (94). This observation was corroborated more recently with ES proteins recovered from sockeye- and Atlantic-fed Lsal appearing at higher concentrations than either coho- or pink-fed Lsal (L. Braden, pers obs). The apparent species-specific response by the parasite was quantified after microarray hybridization, demonstrating that $L s a l$ responds more aggressively to susceptible Atlantic salmon compared to either coho or sockeye salmon (95). Interestingly, in this study there was overexpression of several genes corresponding to proteins described in the secretome $(96,97)$, including putative virulence factors that likely play prominent roles in host immunosuppression and disruption of wound healing (98). Thus, the variable host response to Lsal is multifactorial and involves the interaction between the parasite feeding/attack and host defense responses.

\section{Immunomodulation}

The likelihood of successful parasitism is increased by reducing host awareness of the parasite at the attachment site, which is achieved through immunomodulation (99-101). Ectoparasites secrete a cocktail of highly-evolved pharmacologically active factors in their saliva that manipulate both hemostatic and immune systems (reviewed by (102)), acting to inhibit cutaneous irritation, suppress cellular immunity, prevent blood clotting and interfere with wound healing (103). These molecules have been found to share ancestral homology with host genes or have developed independently and share no identifiable homology to the host (reviewed by (104)). Extensive characterization of these molecules in terrestrial blood-feeding arthropods (e.g., ticks, mites, lice) over the last 100 years indicates functional commonalities that represent convergent evolution across several phylogenetic lineages (105-107)).

The salmon louse has at least four different types of glands that appear to have specialized functions (108). Exocrine glands involved in the production of host-interacting proteins include type 3 tegumental glands and labial glands: the former emptying contents directly onto the host from pores in the marginal membrane, while the latter containing secretory units that empty into storage

This article is protected by copyright. All rights reserved 
reservoirs that are suggested to be involved in mouth tube movement (108). Due to their intimate association with the host it is likely that the contents of both these reservoirs are involved in the hostparasite relationship. Experimental characterization of the proteins excreted and/or secreted (ES proteins) by Lsal has generated a list of potential interacting virulence factors that share significant homology with those described for other ectoparasites $(11,12,96,97)$. Using sequence and domain homology, these can be broadly generalized into five categories of proteins: 1.) Inhibitors of coagulation, 2.) Hemoglobinolytic enzymes, 3.) Anti-immunity, 4.) Anti-microbial, and 5.) Antiwound healing, with several proteins not falling into any category and thus having unknown function (Figure 1C\&D, Table 1).

For parasites that rely on blood as a source of energy, including Lsal, a critical adaptation has been the evolution of strategies to inhibit the host clotting cascade and enhance digestion of clots via fibrinolysis. In other parasites the presence of proteins involved in these processes is well documented (109-117). Similarly, the Lsal secretome is populated with anti-clotting proteins including alpha-2macroglobulin, serine protease inhibitors, carboxypeptidase B, and coagulation factor IX (96,97). The extent of louse-associated interference of host coagulation and fibrinolysis was recently demonstrated in the putative louse-salmon interactome (Figure 3), where key virulence factors in the secretome were shown by an interolog-approach (a conserved interaction between a pair of proteins which have interacting homologs in another organism; (118)) to interact with critical components of the salmon host clotting and coagulation cascade such as kininogenin and plasminogen $(96,97)$.

The degradative pathway of hemoglobin has been extensively characterized in hematophagous parasites with perhaps the most comprehensive description in that of Ixodes ricinus (119); however, there is remarkable similarity in the pathway among lineages, with digestion based on cooperating acidic aspartic and cysteine peptidases. Hematophagous arthropods either rely on alkaline proteolysis performed by serine peptidases (e.g., fleas), cysteine peptidases (e.g., ticks), or both serine and cysteine peptidases (e.g., triatomid bugs) for hemoglobin digestion (reviewed by (120)). The pathway of blood digestion in Lsal has not been elucidated; however, there is an abundance of serine-type peptidases characterized in the ES proteome which might indicate a similar digestive strategy to schistosomes ((121), Table 1). Changes in the proportion of serine endopeptidases and cysteine 
proteases in the ES of Lsal between pre-adult and adult life stages suggests varying immune evasion and digestion activity is life stage dependent, even when lice are mobile (96).

While feeding for extended periods of time, ectoparasites compromise the epithelium which in an aqueous environment, permits colonization by opportunistic pathogens. This has led to the notion that Lsal may facilitate infections with bacteria or virus (122). Despite this, when examined histologically, epithelial wounds caused by Lsal are rarely associated with bacterial colonization, and when they have been observed it has been on the fins and gills $>150$ degree-days $(123,124)$. Even in cases where salmon have been co-exposed with Moritella viscosa, the bacteria was rarely isolated from Lsal attachment sites $(<5 \%)$, despite common clinical signs of 'winter ulcer disease' and bacterial isolation from other skin sites away from louse attachment (125). Interestingly, the feeding response of Lsal is associated with significant production of vitellogenin-like proteins. Primarily associated with egg-yolk production, vitellogenins have also been implicated to act in non-reproductive roles including immunity and protection against oxidants (126). In honeybees Apis mellifera vitellogenins in the venom are associated with antimicrobial activities (127), and vitellogenins are a major salivary antigen of ectoparasitic sheep scab mites Psoroptes ovis (128). The most abundant proteins in the Lsal secretome are vitellogenin-like proteins $(96,97)$, suggesting they play an important non-reproductive role in the host-parasite interaction. However, this hypothesis requires experimental validation.

As the fundamental barrier in an aqueous environment, teleost skin is in a constant state of flux and is therefore extremely proficient at repairing damage within short periods of time as well as preventing pathogen colonization $(96,97)$. Wound healing includes the highly regulated and overlapping processes of hemostasis, inflammation, proliferation, formation of granular tissue, reepithelialization, matrix formation, and tissue remodelling $(129,130)$, with genetic and mechanistic conservation between mammals and teleosts (131). However, in teleost fishes, the process of reepithelization is faster, with full-thickness wounds approaching 100\% closure within 12 hrs of injury and independent of coagulation or inflammation (132). Thus, for the ectoparasitic salmon louse, inhibition of host wound healing would likely be of considerable importance. It appears that a major function of Lsal virulence is interference with wound healing by chemically disrupting fibrinolysis. For example, the parasite secretes several proteins including collagenase and serine proteases that are predicted to interact with fibronectin, a critical component of wound healing and tissue remodeling 
(133). The large number of ES proteins targeting extracellular matrix regeneration and collagen deposition in the host emphasizes the importance of this pathway during the louse-salmon interaction (98). Interestingly, expression of louse proteins that target wound healing and tissue remodeling is enhanced while parasitizing the more susceptible species (95), the phenotype of which is characterized by a poor wound healing response.

Blood-feeding arthropods must contend with their host's blood coagulation cascade, the toxic components of iron and heme, and also must circumvent host immunity. This is perhaps even more critical in parasites that feed on their hosts for an extended period of time, such as with salmon lice, in contrast to mosquitos (Aedes aegypti) which only have a short period of blood feeding before leaving the host. Thus, it is not surprising that among the pharmacologically active molecules present in the ES proteome of Lsal are several anti-immune molecules. For example, hypodermin B (hypB) has been described as a key feeding-associated gene in Lsal, with enhanced expression while feeding on susceptible hosts compared to resistant hosts (95). Furthermore, hypodermin B is routinely identified in the dopamine-elicited ES products of both Pacific and Atlantic subspecies of Lsal (95). Originally described in the cattle grub Hypoderma lineatum this enzyme inhibits the complement cascade by degradation of $\mathrm{C} 3$ as well as assisting parasite migration through degradation of protein in host tissue $(96,97)$. Complement evasion is a common strategy among all classes of parasites (134), and downregulation of genes in both classical and lectin pathways (e.g., clq, mbl, clec2) appears to be a feature of the host response to Lsal and Crog lice infections $(34,35,39)$. This likely inhibits host production of reactive oxygen species (e.g., $\mathrm{H}_{2} \mathrm{O}_{2}$ ) thus effector macrophage activity, which can damage louse cuticle, and host dendritic cell maturation impacting T-cell responsiveness.

There appears to be several cases of divergent evolution in the feeding transcriptome and proteome of Lsal. For example, genes annotated as $\beta$ - and $\gamma$-crystallin in the louse transcriptome are part of the co-regulated suite of virulence-associated transcripts involved in the feeding response on susceptible Atlantic salmon (95). Furthermore, $\beta / \gamma$-crystallins have been identified in the proteome, supporting their role in the host-parasite interaction (97). Crystallins are a diverse group of water soluble, multifunctional proteins that are related to stress or metabolic-associated proteins (135). In higher vertebrates, they appear to only function in the eye lens, but the presence of several crystallinlike proteins with non-optical roles in invertebrates supports mutational diversification throughout 
evolution (135). For example, Piatigorsky et al. (136) showed a jellyfish crystallin-like protein shared between $25-50 \%$ similarity to saposin-containing protein NK-lysin, a saposin-containing protein (SAPLIP). Interestingly, SAPLIPs are prominently featured in the feeding transcriptome of Lsal, and are significantly induced while feeding on susceptible Atlantic salmon (95). These are a diverse family of lipid-interacting proteins that are conserved phylogenetically and have high sequence and function variability (137). SAPLIPs from liver flukes Fasciola hepatica and Clonorchis sinensis, the protistan Entamoeba histolytica, and nematodes Necator americanus play key roles in the hostparasite interaction (138-140). In the ES proteome of Lsal, proteins with saposin-associated domains have been identified, including antimicrobial peptide NK-lysin and saposin-type protein A $(96,97)$. Interestingly, sequence analysis of Lsal NK-lysin indicates this protein is $>35 \%$ similar to amoebapore B, a major virulence factor of Entamoeba spp (139).

To avoid deleterious host immune responses, ectoparasites deploy several classes of proteases that can be characterized by the chemical composition of their active site: cysteine, serine, aspartic, metallo- and threonine. The feeding response of Lsal prominently features expression of serine (e.g., trypsins, chymotrypsins) (Figure 1C\&D), cysteine (e.g., cathepsins), and metalloproteases (e.g., astacins) $(96,97)$. The high number of proteases in the ES proteome indicates the importance of these enzymes during the host-parasite interaction. Indeed, network analysis of the predicted louse-salmon interactome revealed that several of these proteases interact with salmon host proteins involved in inflammatory, extracellular matrix and tissue remodelling processes (98). Thus, the salmon louse may be achieving immunosuppressive effects through the actions of secreted proteases as what is described for many other parasites. For example cysteine proteases from the liver fluke Fasciola hepatica downregulates inflammation by degradation of TLR3, and modulates cellular effectors by cleaving host-derived immunoglobulin (141). Ectoparasite mites and ticks also rely on cysteine proteases as major virulence factors, and the abundance of these proteins in the secretomes of the parasites highlights the importance of these proteases in the host-parasite interaction (142-144). Interestingly, the greatest cathepsin L activity from Lsal has been reported at the sessile chalimus stage, when prevention of immune recognition would be of outmost importance to prevent host rejection (145). Inhibition of host recognition during attached chalimus stages may also be accomplished through production of prostaglandins. For example, Fast et al (146) identified the 
arachidonic acid metabolite $\mathrm{PGE}_{2}$ in the ES products of $\mathrm{Lsal}$ and this was negatively correlated with expression of pro-inflammatory mediators. Secretion of $\mathrm{PGE}_{2}$ is effective in modulating responses of dendritic cells (DCs) in nematodes (147) and ticks $(101,148)$; however, the effect of Lsal-PGE 2 on salmonid DCs has not been quantified and the overall contribution of $\mathrm{PGE}_{2}$ to Lsal virulence remains to be elucidated.

\section{Co-evolutionary Impacts \& Future Perspectives}

Our current understanding of louse immunomodulation of the host is a snapshot of a dynamic relationship after millions of years of co-evolution. Evolutionary theory predicts that the host and parasite could currently be a stable strategy between the host and parasite, could involve static withinpopulation dimorphism or polymorphism; experiencing arms race dynamics, in which the host and parasite are escalating their immune and modulatory responses, respectively, to gain advantage over the other; or finally, there could be fluctuating selection dynamics, due to oscillatory feedbacks from the host and parasite, and these can be enhanced or dampened by environmental and life history inputs (149). As some fitness costs to the host are expected to occur with increased host resistance and parasite virulence (i.e., parasite-derived factors contributing to parasite fitness), arms race dynamics are not expected to continue indefinitely, eventually leading to either a stable strategy between the host and parasite or fluctuating selection dynamics $(149,150)$. Over the last 20-30 years of intensive salmon aquaculture, these dynamics may have been significantly altered, whereby the costs of enhanced louse virulence are reduced with the constant supply of new hosts to the marine environment on a 20-24 month cycle. Recent publications have suggested strong potential for microevolution of virulence in lice and other pathogen populations that can be selected for under intensive aquaculture conditions $(79,149,151)$. Anti-louse medicinal intervention and removal of host populations at harvest may disentangle the natural selection towards host adaptation to combat louse virulence (i.e. reduce pathology) in the cage system and the positive traits normally associated with it such as increased survival and fecundity. While this theory may expect little to no changes in adaptation of the host to the pathogen, Masri et al. (152) has shown that in some cases the presence of co-evolution with the host leads to selective advantage of virulence fixation (i.e., no change in virulence) in the pathogen population, compared to one-sided adaptation. Whether intensive 
aquaculture is enhancing immunomodulatory mechanisms, and thereby virulence in the louse, effectively tipping fluctuating selection dynamics in the parasite's favour over the short-term, or this is a longer-term trend, perhaps our greatest knowledge gap is whether/how this co-evolutionary trajectory might be altered. For example, expression of virulence factors in Lsal are overexpressed while feeding on non-native host populations (e.g., L. salmonis oncorhynchii on Atlantic salmon), which may be disrupting natural evolutionary processes (95). In another parasitic copepod-host system (Mytilicola spp. infecting blue mussels), Feis et al. (153) describe separate invasion fronts lead to different co-evolutionary trajectories (i.e. host resistance, tolerance, susceptibility), and Lsal, among other Caligid copepods, have already demonstrated this within the salmonid host lineage described earlier. However, shifts in these trajectories once established has not been shown.

Theoretical exploration of perturbations to the natural system (i.e. host-parasite co-evolutionary forces) from aquaculture, using different modelling approaches would be an interesting new area of investigation in the future.

Another major knowledge gap we have is the extent of co-evolution of the louse with other potential pathogens of the salmonid host. Overgaard et al. (154), through knock-down studies, observed significant impacts of Lsal rhabdoviruses on subsequent salmon inflammatory/immune responses, potential benefiting the copepod during infection. Co-infection studies also show the synergism between Lsal and another rhabdovirus infection (infectious hematopoetic necrosis virus; IHNV) as well as the orthomyxovirus infectious salmon anemia virus (ISAv), in the salmonid host (74). These synergies are linked to the immunomodulatory capabilities of Lsal dampening inflammation and anti-viral responses in the host. Co-evolutionary selection dynamics on the lousevirus relationship are unknown and how they may enhance or dampen the impacts on the hosts is an important question for both salmonid culture and fisheries ecology.

The development of novel anti-louse treatments relies on a holistic understanding of the hostparasite relationship between $\mathrm{Lsal}$ and its various salmonid hosts. Advances in genomics along with the sequencing and annotation of the salmon louse (155), Atlantic salmon $(156,157)$ and other salmonid species genomes (e.g., (158)) has certainly perpetrated a more thorough understanding of this relationship. However, there are many gaps that need to be addressed, including improved methods to identify secretory products released specifically during the copepodite-chalimus transition

This article is protected by copyright. All rights reserved 
stages and functional characterization of the various virulence factors and their effects on host biology.

\section{References}

1. FAO. Food and Agriculture Organization (FAO) of the United Nations. Fisheries and Aquaculture Department. Cultured Aquatic Species Information Programme: Salmo salar (Linnaeus, 1758). (2019). Available at:

http://www.fao.org/fishery/culturedspecies/Salmo_salar/en

2. Brooker AJ, Skern-Mauritzen R, Bron JE. Production, mortality, and infectivity of planktonic larval sea lice, Lepeophtheirus salmonis (Kroyer, 1837): Current knowledge and implications for epidemiological modelling. ICES J Mar Sci (2018) 75:1214-1234. doi:10.1093/icesjms/fsy015

3. Wootten R, Smith J, Needhama E. Aspects of the biology of the parasitic copepods Lepeophtheirus salmonis and Caligus elongatus on farmed salmonids, and their treatment. Proc R Soc Edinburgh Sect B Biol Sci (1982) 81:185-197. doi:10.1017/S0269727000003389

4. Jackson D, Moberg O, Stenevik Djupevåg EM, Kane F, Hareide H. The drivers of sea lice management policies and how best to integrate them into a risk management strategy: An ecosystem approach to sea lice management. J Fish Dis (2018) 41:927-933. doi:10.1111/jfd.12705

5. Grimnes A, Jakobsen PJ. The physiological effects of salmon lice infection on post-smolt of Atlantic salmon. Jounal Fish Biol (1996) 48:1179-1194. doi:10.1006/jfbi.1996.0119

6. Finstad B, Bjørn P a., Grimnes A, Hvidsten N a., Bjorn P, Grimnes A, Hvidsten N a. Laboratory and field investigations of salmon lice [Lepeophtheirus salmonis (Krøyer)] infestation on Atlantic Salmon (Salmo salar L.) post-smolts. Aquac Res (2000) 31:795-803. doi:10.1046/j.1365-2109.2000.00511.x

7. Jones MW, Sommerville C, Bron J. The histopathology associated with the juvenile stages of Lepeophtheirus salmonis on the Atlantic salmon, Salmo salar L. J Fish Dis (1990) 13:303-310.

8. Johnson SCS, Albright LLJ. Comparative susceptibility and histopathology of the response of naive Atlantic, Chinook and coho salmon to experimental infection with Lepeophtheirus

This article is protected by copyright. All rights reserved 
salmonis (Copepoda: Caligidae). Dis Aquat Organ (1992) 14:179-193. doi:10.3354/dao014179

9. Jonsdottir H, Bron JE, Wootten R, Turnbull JF. The histopathology associated with the preadult and adult stages of Lepeophtheirus salmonis on the Atlantic salmon, Salmo salar L. $J$ Fish Dis (1992) 15:521-527. doi:10.1111/j.1365-2761.1992.tb00684.x

10. Fast MD, Sims DE, Burka JF, Mustafa a., Ross NW. Skin morphology and humoral nonspecific defence parameters of mucus and plasma in rainbow trout, coho and Atlantic salmon. Comp Biochem Physiol - A Mol Integr Physiol (2002) 132:645-657. doi:10.1016/S10956433(02)00109-5

11. Fast MD, Ross NW, Craft CA, Locke SJ, MacKinnon SL, Johnson SC. Lepeophtheirus salmonis: Characterization of prostaglandin E2 in secretory products of the salmon louse by RP-HPLC and mass spectrometry. Exp Parasitol (2004) 107:5-13. doi:10.1016/j.exppara.2004.04.001

12. Fast MD, Johnson SC, Eddy TD, Pinto D, Ross NW. Lepeophtheirus salmonis secretory/excretory products and their effects on Atlantic salmon immune gene regulation. Parasite Immunol (2007) 29:179-189. doi:10.1111/j.1365-3024.2006.00932.x

13. Easy RH, Ross NW. Changes in Atlantic salmon (Salmo salar) epidermal mucus protein composition profiles following infection with sea lice (Lepeophtheirus salmonis). Comp Biochem Physiol - Part D Genomics Proteomics (2009) 4:159-167.

doi:10.1016/j.cbd.2009.02.001

14. Firth KJ, Johnson SC, Ross NW. Characterization of proteases in the skin mucus of Atlantic salmon (Salmo salar) infected with the salmon louse (Lepeophtheirus salmonis) and in wholebody louse homogenate. J Parasitol (2000) 86:1199-1205. doi:10.1645/00223395(2000)086[1199:COPITS]2.0.CO;2

15. Fast MD. Fish immune responses to parasitic copepod (namely sea lice) infection. Dev Comp Immunol (2014) 43:300-312. doi:10.1016/j.dci.2013.08.019

16. Wagner GN, Fast MD, Johnson SC. Physiology and immunology of Lepeophtheirus salmonis infections of salmonids. Trends Parasitol (2008) 24:176-183. doi:10.1016/j.pt.2007.12.010

17. Hamre LA, Eichner C, Caipang CMA, Dalvin ST, Bron JE, Nilsen F, Boxshall G, SkernMauritzen R. The salmon louse Lepeophtheirus salmonis (Copepoda: Caligidae) life cycle has

This article is protected by copyright. All rights reserved 
only two chalimus stages. PLoS One (2013) 8:1-9. doi:10.1371/journal.pone.0073539

18. Eichner C, Hamre LA, Nilsen F. Instar growth and molt increments in Lepeophtheirus salmonis (Copepoda: Caligidae) chalimus larvae. Parasitol Int (2015) 64:86-96.

doi:10.1016/j.parint.2014.10.006

19. Browman HI, Boxaspen K, Kuhn P. The effect of light on the settlement of the salmon louse, Lepeophtheirus salmonis, on Atlantic salmon, Salmo salar L. J Fish Dis (2004) 27:701-708. doi:10.1111/j.1365-2761.2004.00592.x

20. Genna RL, Mordue W, Pike AW, Mordue (Luntz) AJ. Light intensity, salinity, and host velocity influence presettlement intensity and distribution on hosts by copepodids of sea lice, Lepeophtheirus salmonis. Can J Fish Aquat Sci (2005) 62:2675-2682. doi:10.1139/f05-163

21. Mordue AJ, Birkett MA. A review of host finding behaviour in the parasitic sea louse, Lepeophtheirus salmonis (Caligidae: Copepoda). J Fish Dis (2009) 32:3-13. doi:10.1111/j.1365-2761.2008.01004.x

22. Ingvarsdóttir A, Birkett M, Duce I, Genna RL, Mordue W, Pickett J, Wadhams LJ, Mordue J. Semiochemical strategies for sea louse control: Host location cues. Pest Manag Sci (2002) 58:537-545. doi:10.1002/ps.510

23. Bailey RJE, Birkett M, Ingvarsdóttir A, Luntz JM, Mordue W, Shea BO, Pickett J, Wadhams LJ. The role of semiochemicals in host location and non-host avoidance by salmon louse (Lepeophtheirus salmonis) copepodids. Can J Fish Aquat Sci (2006) 63:448-456. doi:10.1139/f05-231

24. Komisarczuk AZ, Grotmol S, Nilsen F. Ionotropic receptors signal host recognition in the salmon louse (Lepeophtheirus salmonis, copepoda). PLoS One (2017) 12:1-18. doi:10.1371/journal.pone.0178812

25. Bron JE. A study of the biology and behaviour of the copepodid larva of the salmon louse Lepeophtheirus salmonis (Kroyer, 1837) (Copepoda; Caligidae). (1993)

26. Bron JE, Sommerville C, Jones M, Rae GH. The settlement and attachment of early stages of the salmon louse, Lepeophtheirus salmonis (Copepoda: Caligidae) on the salmon host, Salmo salar. J Zool (1991) 224:201-212. doi:10.1111/j.1469-7998.1991.tb04799.x

27. Johnson SC, Albright LJ. Effects of cortisol implants on the susceptibility and the

This article is protected by copyright. All rights reserved 
histopathology of the responses of naive coho salmon Oncorhynchus kisutch to experimental infection with Lepeophtheirus salmonis (Copepoda: Caligidae). Dis Aquat Organ (1992)

\section{4:195-205. doi:10.3354/dao014195}

28. Boxaspen K. A review of the biology and genetics of sea lice. ICES J Mar Sci (2006) 63:13041316. doi:10.1016/j.icesjms.2006.04.017

29. Pike AW, Wadsworth S. Sea lice on salmonids: their biology and control. Adv Parasitol (1999) 44:233-337.

30. Brandal PO, Egidius E, Romslo I. Host blood: a major food component for the parasitic copepod Lepeophtheirus salmonis Kroyeri, 1838 (Crustacea: Caligidae). Norweigan J Zool (1976) 24:341-343.

31. Haji Hamid HL, Bron JE, Shin AP, Sommerville C. The occurrence of blood feeding in Lepeophtheirus salmonis. in Fourth International Crustacean Congress (Amsterdam, The Netherlands).

32. Bowers JM, Mustafa A, Speare DJ, Conboy G a., Brimacombe M, Sims DE, Burka JF. The physiological response of Atlantic salmon, Salmo salar L., to a single experimental challenge with sea lice, Lepeophtheirus salmonis. J Fish Dis (2000) 23:165-172. doi:10.1046/j.13652761.2000.00225.x

33. Fast MD, Muise DM, Easy RE, Ross NW, Johnson SC. The effects of Lepeophtheirus salmonis infections on the stress response and immunological status of Atlantic salmon (Salmo salar). Fish Shellfish Immunol (2006) 21:228-241. doi:10.1016/j.fsi.2005.11.010

34. Skugor S, Glover KAA, Nilsen F, Krasnov A. Local and systemic gene expression responses of Atlantic salmon (Salmo salar L.) to infection with the salmon louse (Lepeophtheirus salmonis). BMC Genomics (2008) 9:498. doi:10.1186/1471-2164-9-498

35. Tadiso TM, Krasnov A, Skugor S, Afanasyev S, Hordvik I, Nilsen F. Gene expression analyses of immune responses in Atlantic salmon during early stages of infection by salmon louse (Lepeophtheirus salmonis) revealed bi-phasic responses coinciding with the copepod-chalimus transition. BMC Genomics (2011) 12:141. doi:10.1186/1471-2164-12-141

36. Holm HJ, Skugor S, Bjelland AK, Radunovic S, Wadsworth S, Koppang EO, Evensen. Contrasting expression of immune genes in scaled and scaleless skin of Atlantic salmon 
infected with young stages of Lepeophtheirus salmonis. Dev Comp Immunol (2017) 67:153165. doi:10.1016/j.dci.2016.10.008

37. Holm H, Santi N, Kjøglum S, Perisic N, Skugor S, Evensen Ø. Difference in skin immune responses to infection with salmon louse (Lepeophtheirus salmonis) in Atlantic salmon (Salmo salar L.) of families selected for resistance and susceptibility. Fish Shellfish Immunol (2015) 42:384-394. doi:10.1016/j.fsi.2014.10.038

38. Robledo D, Gutiérrez AP, Barría A, Lhorente JP, Houston RD, Yáñez JM. Discovery and Functional Annotation of Quantitative Trait Loci Affecting Resistance to Sea Lice in Atlantic Salmon. Front Genet (2019) 10:1-10. doi:10.3389/fgene.2019.00056

39. Robledo D, Gutiérrez AP, Barría A, Yáñez JM, Houston RD. Gene expression response to sea lice in Atlantic salmon skin: RNA sequencing comparison between resistant and susceptible animals. Front Genet (2018) 9:1-10. doi:10.3389/fgene.2018.00287

40. Gallardo-Escárate C, Valenzuela-Muñoz V, Núñez-Acuña G, Carrera C, Gonçalves AT, Valenzuela-Miranda D, Benavente BP, Roberts S. Catching the complexity of salmon-louse interactions. Fish Shellfish Immunol (2019) 90:199-209. doi:10.1016/j.fsi.2019.04.065

41. Glover K, Aasmundstad T, Nilsen F, Storset A, Skaala. Variation of Atlantic salmon families (Salmo salar L.) in susceptibility to the sea lice Lepeophtheirus salmonis and Caligus elongatus. Aquaculture (2005) 245:19-30. doi:10.1016/j.aquaculture.2004.11.047

42. Bron J, Gharbi K, Tinch A, Roberts R, Stear M, Matthews L. The control of sea lice in Atlantic salmon by selective breeding. J R Soc Interface (2015) 12:20150574.

doi:10.1098/rsif.2015.0574

43. Tsai H-Y, Hamilton A, Tinch AE, Guy DR, Bron JE, Taggart JB, Gharbi K, Stear M, Matika O, Pong-Wong R, et al. Genomic prediction of host resistance to sea lice in farmed Atlantic salmon populations. Genet Sel Evol (2016) 48:47. doi:10.1186/s12711-016-0226-9

44. Baranzini SE. The role of antiproliferative gene Tob1 in the immune system. Clin Exp Neuroimmunol (2014) 5:132-136. doi:10.1038/jid.2014.371

45. Sutherland BJG, Koczka KW, Yasuike M, Jantzen SG, Yazawa R, Koop BF, Jones SRM. Comparative transcriptomics of Atlantic Salmo salar, chum Oncorhynchus keta and pink salmon O. gorbuscha during infections with salmon lice Lepeophtheirus salmonis. BMC

This article is protected by copyright. All rights reserved 
Genomics (2014) 15:200. doi:10.1186/1471-2164-15-200

46. Braden LM, Koop BF, Jones SRM. Signatures of resistance to Lepeophtheirus salmonis include a Th2-type response at the louse-salmon interface. Dev Comp Immunol (2015) 48:178191.

47. Krasnov A, Wesmajervi Breiland MS, Hatlen B, Afanasyev S, Skugor S. Sexual maturation and administration of $17 \beta$-estradiol and testosterone induce complex gene expression changes in skin and increase resistance of Atlantic salmon to ectoparasite salmon louse. Gen Comp Endocrinol (2015) 212:34-43. doi:10.1016/j.ygcen.2015.01.002

48. Sutherland BJG, Jantzen SG, Sanderson DS, Koop BF, Jones SRM. Differentiating sizedependent responses of juvenile pink salmon (Oncorhynchus gorbuscha) to sea lice (Lepeophtheirus salmonis) infections. Comp Biochem Physiol - Part D Genomics Proteomics (2011) 6:213-223. doi:10.1016/j.cbd.2011.04.001

49. Fast MD, Ross NW, Mustafa A, Sims DE, Johnson SC, Conboy GA, Speare DJ, Johnson G, Burka JF. Susceptibility of rainbow trout Oncorhynchus mykiss, Atlantic salmon Salmo salar and coho salmon Oncorhynchus kisutch to experimental infection with sea lice Lepeophtheirus salmonis. Dis Aquat Organ (2002) 52:57-68. doi:10.3354/dao052057

50. Mustafa A, MacWilliams C, Fernandez N, Matchett K, Conboy G a, Burka JF. Effects of sea lice (Lepeophtheirus salmonis Kröyer, 1837) infestation on macrophage functions in Atlantic salmon (Salmo salar L.). Fish Shellfish Immunol (2000) 10:47-59. doi:10.1006/fsim.1999.0229

51. Braden LM, Barker DE, Koop BF, Jones SRM. Comparative defense-associated responses in salmon skin elicited by the ectoparasite Lepeophtheirus salmonis. Comp Biochem Physiol Part D Genomics Proteomics (2012) 7:100-109. doi:10.1016/j.cbd.2011.12.002

52. Krasnov A, Skugor S, Todorcevic M, Glover K, Nilsen F. Gene expression in Atlantic salmon skin in response to infection with the parasitic copepod Lepeophtheirus salmonis, cortisol implant, and their combination. BMC Genomics (2012) 13:130. doi:10.1186/1471-2164-13-130

53. Nagase H. Matrix Metalloproteinases. J Biol Chem (1999) 274:21491-21494. doi:10.1074/jbc.274.31.21491

54. Xue M, Le NT V, Jackson CJ. Targeting matrix metalloproteases to improve cutaneous wound healing. Expert Opin Ther Targets (2006) 10:143-155. doi:10.1517/14728222.10.1.143

This article is protected by copyright. All rights reserved 
55. Grayson TH, Jenkins PG, Wrathmell AB, Harris JE. Serum responses to the salmon louse, Lepeophtheirus salmonis (Kroyer, 1838), in naturally infected salmonids and immunised rainbow trout, Oncorhynchus mykiss (Walbaum), and rabbits. Fish Shellfish Immunol (1991) 1:141-155. doi:10.1016/S1050-4648(06)80014-8

56. Grayson TH, John RJ, Wadsworth S, Greaves K, Cox D, Roper J, Wrathmell a B, Gilpin ML, Harris JE, Coxf D. Immunization of Atlantic salmon against the salmon louse: Identification of antigens and effects on louse fecundity. J Fish Biol (1995) 47:85-94. doi:10.1111/j.10958649.1995.tb06046.x

57. Raynard RS, Bricknell IR, Billingsley PF, Nisbet AJ, Vigneau A, Sommerville C. Development of vaccines against sea lice. Pest Manag Sci (2002) 58:569-575. doi:10.1002/ps.474

58. Carpio Y, Basabe L, Acosta J, Rodríguez A, Mendoza A, Lisperger A, Zamorano E, González $\mathrm{M}$, Rivas M, Contreras S, et al. Novel gene isolated from Caligus rogercresseyi: A promising target for vaccine development against sea lice. Vaccine (2011) 29:2810-2820. doi:10.1016/j.vaccine.2011.01.109

59. Gjerde B, Ødegård J, Thorland I. Estimates of genetic variation in the susceptibility of Atlantic salmon (Salmo salar) to the salmon louse Lepeophtheirus salmonis. Aquaculture (2011) 314:66-72. doi:10.1016/j.aquaculture.2011.01.026

60. Contreras M, Karlsen M, Villar M, Olsen RH, Leknes LM, Furevik A, Yttredal KL, Tartor H, Grove S, Alberdi P, et al. Vaccination with ectoparasite proteins involved in midgut function and blood digestion reduces salmon louse infestations. Vaccines (2020) 8:1-17. doi:10.3390/vaccines 8010032

61. Jensen LB, Provan F, Larssen E, Bron JE, Obach A. Reducing sea lice (Lepeophtheirus salmonis) infestation of farmed Atlantic salmon (Salmo salar L.) through functional feeds. Aquac Nutr (2014)n/a-n/a. doi:10.1111/anu.12222

62. Chang BD, Page FH, Beattie MJ, Hill BWH. "Sea louse abundance on farmed salmon in Southwestern New Brunswick area of the Bay of Fundy," in Salmon Lice: An Integrated Approach to Understanding Parasite Abundance and Distribution, eds. S. R. M. Jones, R. J. Beamish (Wiley \& Sons Ltd.), 83-115.

This article is protected by copyright. All rights reserved 
63. Lees F, Gettinby G, Revie CW. Changes in epidemiological patterns of sea lice infestation on farmed Atlantic salmon, Salmo salar L., in Scotland between 1996 and 2006. J Fish Dis (2008) 31:259-268. doi:10.1111/j.1365-2761.2007.00897.x

64. Aaen SM, Helgesen KO, Bakke MJ, Kaur K, Horsberg TE. Drug resistance in sea lice: A threat to salmonid aquaculture. Trends Parasitol (2015) 31:72-81. doi:10.1016/j.pt.2014.12.006

65. Helgesen KO, Marin SL, Fast MD. "An Emerging Threat: Sea Lice Resistance," in An overview of emerging diseases in the salmonid farming industry, 5-15.

66. Nilsen F. Recent advances in salmon louse research. Bull Eur Assoc Fish Pathol (2018) 38:9197.

67. Bui S, Oppedal F, Stien L, Dempster T. Sea lice infestation level alters salmon swimming depth in sea-cages. Aquac Environ Interact (2016) 8:429-435. doi:10.3354/AEI00188

68. Frenzl B, Stien LH, Cockerill D, Oppedal F, Richards RH, Shinn AP, Bron JE, Migaud H. Manipulation of farmed Atlantic salmon swimming behaviour through the adjustment of lighting and feeding regimes as a tool for salmon lice control. Aquaculture (2014) 424 425:183-188. doi:10.1016/j.aquaculture.2013.12.012

69. Stien LH, Dempster T, Bui S, Glaropoulos A, Fosseidengen JE, Wright DW, Oppedal F. "Snorkel" sea lice barrier technology reduces sea lice loads on harvest-sized Atlantic salmon with minimal welfare impacts. Aquaculture (2016) 458:29-37.

doi:10.1016/j.aquaculture.2016.02.014

70. Frank K, Gansel LC, Lien AM, Birkevold J. Effects of a Shielding Skirt for Prevention of Sea Lice on the Flow Past Stocked Salmon Fish Cages. J Offshore Mech Arct Eng (2014) 137:011201. doi:10.1115/1.4028260

71. Brooker AJ, Papadopoulou A, Gutierrez C, Rey S, Davie A, Migaud H. Sustainable production and use of cleaner fish for the biological control of sea lice: Recent advances and current challenges. Vet Rec (2018) 183:383. doi:10.1136/vr.104966

72. Overton K, Dempster T, Oppedal F, Kristiansen TS, Gismervik K, Stien LH. Salmon lice treatments and salmon mortality in Norwegian aquaculture: a review. Rev Aquac (2018)1-20. doi:10.1111/raq.12299

73. Guðmundsdóttir S, Vendramin N, Cuenca A, Sigurðardóttir H, Kristmundsson A, Iburg TM, 
Olesen NJ. Outbreak of viral haemorrhagic septicaemia (VHS) in lumpfish (Cyclopterus lumpus) in Iceland caused by VHS virus genotype IV. J Fish Dis (2019) 42:47-62. doi:10.1111/jfd.12910

74. Barker SE, Bricknell IR, Covello J, Purcell S, Fast MD, Wolters W, Bouchard DA. Sea lice, Lepeophtheirus salmonis (Krøyer 1837), infected Atlantic salmon (Salmo salar L.) are more susceptible to infectious salmon anemia virus. PLoS One (2019) 14:1-28. doi:10.1371/journal.pone.0209178

75. Figueroa C, Bustos P, Torrealba D, Dixon B, Soto C, Conejeros P, Gallardo JA. Coinfection takes its toll: Sea lice override the protective effects of vaccination against a bacterial pathogen in Atlantic salmon. Sci Rep (2017) 7:1-8. doi:10.1038/s41598-017-18180-6

76. Treasurer JW, Wadsworth S, Grant A. Resistance of sea lice, Lepeophtheirus salmonis (Kroyer), to hydrogen peroxide on farmed Atlantic salmon, Salmo salar L. Aquac Res (2000) 31:855-860. doi:10.1046/j.1365-2109.2000.00517.x

77. Ljungfeldt LER, Quintela M, Besnier F, Nilsen F, Glover KA. A pedigree-based experiment reveals variation in salinity and thermal tolerance in the salmon louse, Lepeophtheirus salmonis. Evol Appl (2017) 10:1007-1019. doi:10.1111/eva.12505

78. Sievers M, Oppedal F, Ditria E, Wright DW. The effectiveness of hyposaline treatments against host-attached salmon lice. Sci Rep (2019) 9:1-10. doi:10.1038/s41598-019-43533-8

79. Ugelvik MS, Skorping A, Moberg O, Mennerat A. Evolution of virulence under intensive farming: salmon lice increase skin lesions and reduce host growth in salmon farms. $J$ Evol Biol (2017) 30:1136-1142. doi:10.1111/jeb.13082

80. Torrissen O, Jones S, Asche F, Guttormsen a., Skilbrei OT, Nilsen F, Horsberg TE, Jackson D. Salmon lice - impact on wild salmonids and salmon aquaculture. J Fish Dis (2013) 36:171194. doi:10.1111/jfd. 12061

81. Jones SRM, Hargreaves NB. Infection threshold to estimate Lepeophtheirus salmonisassociated mortality among juvenile pink salmon. Dis Aquat Organ (2009) 84:131-137. doi:10.3354/dao02043

82. Long A, Garver KA, Jones SRM. Synergistic osmoregulatory dysfunction during salmon lice (Lepeophtheirus salmonis) and infectious hematopoietic necrosis virus co-infection in sockeye

This article is protected by copyright. All rights reserved 
salmon (Oncorhynchus nerka) smolts. J Fish Dis (2019)869-882. doi:10.1111/jfd.12989

83. Jones S, Kim E, Bennett W. Early development of resistance to the salmon louse, Lepeophtheirus salmonis (Krøyer), in juvenile pink salmon, Oncorhynchus gorbuscha (Walbaum). J Fish Dis (2008) 31:591-600. doi:10.1111/j.1365-2761.2008.00933.x

84. Jones SRM, Fast MD, Johnson SC. Influence of reduced feed ration on Lepeophtheirus salmonis infestation and inflammatory gene expression in juvenile pink salmon. J Aquat Anim Health (2008) 20:103-109. doi:10.1577/H07-014.1

85. Long A, Garver KA, Jones SRM. Differential effects of adult salmon lice Lepeophtheirus salmonis on physiological responses of Sockeye Salmon and Atlantic Salmon. J Aquat Anim Health (2019) 31:75-87. doi:10.1002/aah.10053

86. Jones SRM, Fast MD, Johnson SC, Groman DB. Differential rejection of salmon lice by pink and chum salmon: Disease consequences and expression of proinflammatory genes. Dis Aquat Organ (2007) 75:229-238. doi:10.3354/dao075229

87. Dawson LHJ, Pike AW, Houlihan DF, Mcvicar AH. Comparison of the susceptibility of sea trout (Salmo trutta L.) and Atlantic salmon (Salmo salar L.) to sea lice (Lepeophtheirus salmonis (Kroyer, 1837)) infections. ICES J Mar Sci (1997) 54:1129-1139.

88. Kolstad K, Heuch PA, Gjerde B, Gjedrem T, Salte R. Genetic variation in resistance of Atlantic salmon (Salmo salar) to the salmon louse Lepeophtheirus salmonis. Aquaculture (2005) 247:145-151. doi:10.1016/j.aquaculture.2005.02.009

89. Nagasawa K. Sea lice, Lepeophtheirus salmonis and Caligus orientalis (Copepoda: Caligidae), of wild and farmed fish in sea and brackish waters of Japan and adjacent regions: A review. Zool Stud (2004) 43:173-178.

90. Braden LM, Barker DE, Koop BF, Jones SRM. Differential modulation of resistance biomarkers in skin of juvenile and mature pink salmon, Oncorhynchus gorbuscha by the salmon louse, Lepeophtheirus salmonis. Fish Shellfish Immunol (2015) 47:7-14. doi:10.1016/j.fsi.2015.08.008

91. Beamish RJ, Neville CM, Sweeting RM, Ambers N. Sea lice on adult Pacific salmon in the coastal waters of Central British Columbia, Canada. Fish Res (2005) 76:198-208. doi:10.1016/j.fishres.2005.06.007

This article is protected by copyright. All rights reserved 
92. Jones S. Mechanisms of Resistance among Salmon to the Parasitic Copepod Lepeophtheirus salmonis. Aquac Res Dev (2011) doi:10.4172/2155-9546.S2-003

93. Lewis DL, Barker DE, McKinley RS. Modulation of cellular innate immunity by Lepeophtheirus salmonis secretory products. Fish Shellfish Immunol (2014) 38:175-183. doi:10.1016/j.fsi.2014.03.014

94. Fast MD, Burka JF, Johnson SC, Ross NW. Enzymes released from Lepeophtheirus salmonis in response to mucus from different salmonids. J Parasitol (2003) 89:7-13. doi:10.1645/00223395(2003)089[0007:ERFLSI]2.0.CO;2

95. Braden LM, Sutherland BJG, Koop BF, Jones SRM. Enhanced transcriptomic responses in the Pacific salmon louse Lepeophtheirus salmonis oncorhynchi to the non-native Atlantic Salmon Salmo salar suggests increased parasite fitness. BMC Genomics (2017) 18:110. doi:10.1186/s12864-017-3520-1

96. Hamilton S, McLean K, Monaghan SJ, McNair C, Inglis NF, McDonald H, Adams S, Richards R, Roy W, Smith P, et al. Characterisation of proteins in excretory/secretory products collected from salmon lice, Lepeophtheirus salmonis. Parasites and Vectors (2018) 11:1-9. doi:10.1186/s13071-018-2885-6

97. Braden LM. Investigating the molecular basis for resistance to the sea louse, Lepeophtheirus salmonis, among salmonids. (2015)

98. Braden LM, Cai W, Michaud D, Poley JD, Fast MD. Pathways of virulence in the salmonlouse host-parasite relationship. in International Society of Animal Genetics

99. Wikel SK, Alarcon-Chaidez FJ. Progress toward molecular characterization of ectoparasite modulation of host immunity. Vet Parasitol (2001) 101:275-287. doi:10.1016/S03044017(01)00556-8

100. Sitjà-Bobadilla A. Living off a fish: A trade-off between parasites and the immune system. Fish Shellfish Immunol (2008) 25:358-372. doi:10.1016/j.fsi.2008.03.018

101. Oliveira CJF, Sá-Nunes A, Francischetti IMB, Carregaro V, Anatriello E, Silva JS, De Miranda Santos IKF, Ribeiro JMC, Ferreira BR. Deconstructing tick saliva: Non-protein molecules with potent immunomodulatory properties. J Biol Chem (2011) 286:10960-10969. doi:10.1074/jbc.M110.205047

This article is protected by copyright. All rights reserved 
102. Mans BJ. Evolution of vertebrate hemostatic and inflammatory control mechanisms in bloodfeeding arthropods. J Innate Immun (2011) 3:41-51. doi:10.1159/000321599

103. Wikel SK. Modulation of the host immune system by ectoparasitic arthropods. Bioscience (1999) 49:311-320.

104. Maizels RM, Smits HH, McSorley HJ. Modulation of Host Immunity by Helminths: The Expanding Repertoire of Parasite Effector Molecules. Immunity (2018) 49:801-818. doi:10.1016/j.immuni.2018.10.016

105. Karkowska-Kuleta J, Kozik A. Moonlighting proteins as virulence factors of pathogenic fungi, parasitic protozoa and multicellular parasites. Mol Oral Microbiol (2014) 29:270-283. doi:10.1111/omi.12078

106. Cuesta-astroz Y, Santos A, Oliveira G, Jensen LJ. Analysis of Predicted Host - Parasite Interactomes Reveals Commonalities and Specificities Related to Parasitic Lifestyle and Tissues Tropism. Front Immunol (2019) 10:212. doi:10.3389/fimmu.2019.00212

107. Sajid M, McKerrow JH. Cysteine proteases of parasitic organisms. Mol Biochem Parasitol (2002) 120:1-21. doi:10.1016/S0166-6851(02)00043-9

108. Øvergård AC, Hamre LA, Harasimczuk E, Dalvin S, Nilsen F, Grotmol S. Exocrine glands of Lepeophtheirus salmonis (Copepoda: Caligidae): Distribution, developmental appearance, and site of secretion. J Morphol (2016) 277:1616-1630. doi:10.1002/jmor.20611

109. Prevot PP, Adam B, Boudjeltia KZ, Brossard M, Lins L, Cauchie P, Brasseur R, Vanhaeverbeek M, Vanhamme L, Godfroid E. Anti-hemostatic effects of a serpin from the saliva of the tick Ixodes ricinus. J Biol Chem (2006) 281:26361-26369. doi:10.1074/jbc.M604197200

110. Bakshi M, Kim TK, Mulenga A. Disruption of blood meal-responsive serpins prevents Ixodes scapularis from feeding to repletion. Ticks Tick Borne Dis (2018) 9:506-518.

doi:10.1016/j.ttbdis.2018.01.001

111. Manship BM, Walker AJ, Jones LA, Davies AJ. Blood feeding in juvenile Paragnathia formica (Isopoda: Gnathiidae): biochemical characterization of trypsin inhibitors, detection of anticoagulants, and molecular identification of fish hosts. Parasitology (2012) 139:744-754. doi:10.1017/S0031182011002320

This article is protected by copyright. All rights reserved 
112. Corral-Rodríguez MÁ, Macedo-Ribeiro S, Barbosa Pereira PJ, Fuentes-Prior P. Tick-derived Kunitz-type inhibitors as antihemostatic factors. Insect Biochem Mol Biol (2009) 39:579-595. doi:10.1016/j.ibmb.2009.07.003

113. Dai SX, Zhang A Di, Huang JF. Evolution, expansion and expression of the Kunitz/BPTI gene family associated with long-term blood feeding in Ixodes scapularis. BMC Evol Biol (2012) 12: doi:10.1186/1471-2148-12-4

114. Kazimírová M, Šulanová M, Trimnell a. R, Kozánek M, Vidlička L, Labuda M, Nuttall P a. Anticoagulant activities in salivary glands of tabanid flies. Med Vet Entomol (2002) 16:301309. doi:10.1046/j.1365-2915.2002.00379.x

115. Wang X, Ribeiro JMC, Broce AB, Wilkerson MJ, Kanost MR. An insight into the transcriptome and proteome of the salivary gland of the stable fly, Stomoxys calcitrans. Insect Biochem Mol Biol (2009) 39:607-614. doi:10.1016/j.ibmb.2009.06.004

116. Kim TK, Tirloni L, Radulovic Z, Lewis L, Bakshi M, Hill C, da Silva Vaz I, Logullo C, Termignoni C, Mulenga A. Conserved Amblyomma americanum tick Serpin19, an inhibitor of blood clotting factors Xa and XIa, trypsin and plasmin, has anti-haemostatic functions. Int $J$ Parasitol (2015) 45:613-627. doi:10.1016/j.jpara.2015.03.009

117. Mans BJ, Louw AI, Neitz AWH. Evolution of hematophagy in ticks: Common-origins for blood coagulation and platelet aggregation inhibitors from soft ticks of the genus Ornithodoros. Mol Biol Evol (2002) 19:1695-1705. doi:10.1093/oxfordjournals.molbev.a003992

118. Walhout AJM, Sordella R, Lu X, Hartley J, Temple GF, Brasch MA, Thierry-Mieg N, Vidal M. Protein interaction mapping in C. elegans Using proteins involved in vulval development. Science (80-) (2000) 287:116-122. doi:10.1126/science.287.5450.116

119. Horn M, Nussbaumerová M, Sanda M, Kovárová Z, Srba JJ, Franta ZZ, Sojka D, Bogyo M, Caffrey CR, Kopácek P, et al. Hemoglobin digestion in blood-feeding ticks: mapping a multipeptidase pathway by functional proteomics. Chem Biol (2009) 16:1053-1063. doi:10.1016/j.chembiol.2009.09.009

120. Caffrey CR, McKerrow JH, Salter JP, Sajid M. Blood "n" guts: An update on schistosome digestive peptidases. Trends Parasitol (2004) 20:241-248. doi:10.1016/j.pt.2004.03.004

121. Dvorak J, Horn M. Serine proteases in schistosomes and other trematodes. Int J Parasitol

This article is protected by copyright. All rights reserved 
(2018) 48:333-344. doi:10.1016/j.ijpara.2018.01.001

122. Santiago PB, De Araújo CN, Motta FN, Praça YR, Charneau S, Bastos IMD, Santana JM. Proteases of haematophagous arthropod vectors are involved in blood-feeding, yolk formation and immunity - a review. Parasites and Vectors (2017) 10:1-20. doi:10.1186/s13071-0172005-z

123. Barker DE, Braden LM, Coombs MP, Boyce B. Preliminary studies on the isolation of bacteria from sea lice, Lepeophtheirus salmonis, infecting farmed salmon in British Columbia, Canada. Parasitol Res (2009) 105:1173-1177. doi:10.1007/s00436-009-1523-9

124. Nylund A, Hovland T, Hodneland K, Nilsen F, Lovik P. Mechanisms for transmission of infectious salmon anaemia (ISA). Dis Aquat Organ (1994) 19:95-100. doi:10.3354/dao019095

125. Carvalho L, Braden L, Fast M. Impact of co-infection with Lepeophtheirus salmonis and Moritella viscosa on inflammatory and immune responses of Atlantic salmon (Salmo salar). $J$ Fish Dis (2020)

126. Park HG, Lee KS, Kim BY, Yoon HJ, Choi YS, Lee KY, Wan H, Li J, Jin BR. Honeybee (Apis cerana) vitellogenin acts as an antimicrobial and antioxidant agent in the body and venom. Dev Comp Immunol (2018) 85:51-60. doi:10.1016/j.dci.2018.04.001

127. Havukainen H, Münch D, Baumann A, Zhong S, Halskau Ø, Krogsgaard M, Amdam G V. Vitellogenin recognizes cell damage through membrane binding and shields living cells from reactive oxygen species. J Biol Chem (2013) 288:28369-28381. doi:10.1074/jbc.M113.465021

128. Huntley JF, Machell J, Nisbet AJ, Van Den Broek A, Chua KY, Cheong N, Hales BJ, Thomas WR. Identification of tropomyosin, paramyosin and apolipophorin/vitellogenin as three major allergens of the sheep scab mite, Psoroptes ovis. Parasite Immunol (2004) 26:335-342. doi:10.1111/j.0141-9838.2004.00717.x

129. Midwood KS, Williams LV, Schwarzbauer JE. Tissue repair and the dynamics of the extracellular matrix. Int J Biochem Cell Biol (2004) 36:1031-1037. doi:10.1016/j.biocel.2003.12.003

130. Guo S, DiPietro LA. Factors affecting wound healing. J Dent Res (2010) 89:219-229. doi:10.1177/0022034509359125

131. Ingerslev HC, Lunder T, Nielsen ME. Inflammatory and regenerative responses in salmonids

This article is protected by copyright. All rights reserved 
following mechanical tissue damage and natural infection. Fish Shellfish Immunol (2010) 29:440-450. doi:10.1016/j.fsi.2010.05.002

132. Richardson R, Slanchev K, Kraus C, Knyphausen P, Eming S, Hammerschmidt M. Adult zebrafish as a model system for cutaneous wound-healing research. J Invest Dermatol (2013) 133:1655-1665. doi:10.1038/jid.2013.16

133. To WS, Midwood KS. Plasma and cellular fibronectin: distinct and independent functions during tissue repair. Fibrogenesis Tissue Repair (2011) 4:21. doi:10.1186/1755-1536-4-21

134. Shao S, Sun X, Chen Y, Zhan B, Zhu X. Complement evasion: An effective strategy that parasites utilize to survive in the host. Front Microbiol (2019) 10:1-13. doi:10.3389/fmicb.2019.00532

135. Wistow GJ, Piatigorsky J. Lens Crystallins: The evolution and expression of proteins for a highy specialized tissue. Annu Rev Biochem (1988) 57:479-504.

136. Piatigorsky J, Norman B, Dishaw LJ, Kos L, Horwitz J, Steinbach PJ, Kozmik Z. J3-crystallin of the jellyfish lens: similarity to saposins. Proc Natl Acad Sci U S A (2001) 98:12362-7. doi:10.1073/pnas.231310698

137. Bruhn H. A short guided tour through functional and structural features of saposin-like proteins. Biochem J (2005) 389:249-257. doi:10.1042/BJ20050051

138. Willis C, Wang CK, Osman A, Simon A, Pickering D, Mulvenna J, Riboldi-Tunicliffe A, Jones MK, Loukas A, Hofmann A. Insights into the membrane interactions of the saposin-like proteins Na-SLP-1 and Ac-SLP-1 from human and dog hookworm. PLoS One (2011) 6: doi:10.1371/journal.pone.0025369

139. Winkelmann J, Leippe M, Bruhn H. A novel saposin-like protein of Entamoeba histolytica with membrane-fusogenic activity. Mol Biochem Parasitol (2006) 147:85-94. doi:10.1016/j.molbiopara.2006.01.010

140. Don TA, Bethony JM, Loukas A. Saposin-like proteins are expressed in the gastrodermis of Schistosoma mansoni and are immunogenic in natural infections. Int J Infect Dis (2008) 12:3947. doi:10.1016/j.ijid.2007.10.007

141. Prowse RK, Chaplin P, Robinson HC, Spithill TW. Fasciola hepatica cathepsin L suppresses sheep lymphocyte proliferationin vitro and modulates surface CD4 expression on human and

This article is protected by copyright. All rights reserved 
ovine T cells. Parasite Immunol (2002) 24:57-66. doi:10.1046/j.0141-9838.2001.00438.x

142. Franta Z, Sojka D, Frantova H, Dvorak J, Horn M, Srba J, Talacko P, Mares M, Schneider E, Craik CS, et al. IrCL1 - The haemoglobinolytic cathepsin L of the hard tick, Ixodes ricinus. Int J Parasitol (2011) 41:1253-1262. doi:10.1016/j.ijpara.2011.06.006

143. Bartley K, Huntley JF, Wright HW, Nath M, Nisbet AJ. Assessment of cathepsin D and L-like proteinases of poultry red mite, Dermanyssus gallinae (De Geer), as potential vaccine antigens. Parasitology (2012) 139:755-765. doi:10.1017/S0031182011002356

144. Oldiges DP, Parizi LF, Zimmer KR, Lorenzini DM, Seixas A, Masuda A, da Silva Vaz I, Termignoni C. A Rhipicephalus (Boophilus) microplus cathepsin with dual peptidase and antimicrobial activity. Int J Parasitol (2012) 42:635-645. doi:10.1016/j.ijpara.2012.04.013

145. McCarthy E, Cunningham E, Copley L, Jackson D, Johnston D, Dalton JP, Mulcahy G. Cathepsin L proteases of the parasitic copepod, Lepeophtheirus salmonis. Aquaculture (2012) 356-357:264-271. doi:10.1016/j.aquaculture.2012.05.007

146. Fast MD, Ross NW, Johnson SC. Prostaglandin E2 modulation of gene expression in an Atlantic salmon (Salmo salar) macrophage-like cell line (SHK-1). Dev Comp Immunol (2005) 29:951-963. doi:10.1016/j.dci.2005.03.007

147. Laan LC, Williams AR, Stavenhagen K, Giera M, Kooij G, Vlasakov I, Kalay H, Kringel H, Nejsum P, Thamsborg SM, et al. The whipworm (Trichuris suis) secretes prostaglandin E2 to suppress proinflammatory properties in human dendritic cells. FASEB J (2017) 31:719-731. doi:10.1096/fj.201600841R

148. Aljamali M, Bowman AS, Dillwith JW, Tucker JS, Yates GW, Essenberg RC, Sauer JR. Identity and synthesis of prostaglandins in the lone star tick, Amblyomma americanum (L.), as assessed by radio-immunoassay and gas chromatography/mass spectrometry. Insect Biochem Mol Biol (2002) 32:331-41. doi:10.1016/S0965-1748(01)00113-8

149. Best A, Ashby B, White A, Bowers R, Bucking A, Koskella B, Boots M. Host-parasite fluctuating selection in the absence of specificity. Proc R Soc B Biol Sci (2017) 284:20171615. doi:10.1098/rspb.2017.1615

150. Papkou A, Gokhale CS, Traulsen A, Schulenburg H. Host-parasite coevolution: why changing population size matters. Zoology (2016) 119:330-338. doi:10.1016/j.zool.2016.02.001

This article is protected by copyright. All rights reserved 
151. Mennerat A, Hamre L, Ebert D, Nilsen F, Dávidová M, Skorping A. Life history and virulence are linked in the ectoparasitic salmon louse Lepeophtheirus salmonis. J Evol Biol (2012) 25:856-861. doi:10.1111/j.1420-9101.2012.02474.x

152. Masri L, Branca A, Sheppard AE, Papkou A, Laehnemann D, Guenther PS, Prahl S, Saebelfeld M, Hollensteiner J, Liesegang H, et al. Host-pathogen coevolution: The selective advantage of Bacillus thuringiensis virulence and its cry toxin genes. PLoS Biol (2015) 13:1-30. doi:10.1371/journal.pbio.1002169

153. Feis ME, Goedknegt MA, Thieltges DW, Buschbaum C, Wegner KM. Coevolutionary Trajectories Along Separate Parasite Invasion Fronts. Zoology (2016) 119:366-374. doi:10.1016/j.zool.2016.05.012

154. Øvergård AC, Hamre LA, Kongshaug H, Nilsen F. RNAi-mediated treatment of two vertically transmitted rhabdovirus infecting the salmon louse (Lepeophtheirus salmonis). Sci Rep (2017) 7:1-10. doi:10.1038/s41598-017-14282-3

155. Yazawa R, Yasuike M, Leong J, Von Schalburg KR, Cooper G a., Beetz-Sargent M, Robb A, Davidson WS, Jones SRM, Koop BF. EST and mitochondrial DNA sequences support a distinct Pacific form of salmon louse, Lepeophtheirus salmonis. Mar Biotechnol (2008) 10:741-749. doi:10.1007/s10126-008-9112-y

156. Davidson WS, Koop BF, Jones SJM, Iturra P, Vidal R, Maass A, Jonassen I, Lien S, Omholt SW. Sequencing the genome of the Atlantic salmon (Salmo salar). Genome Biol (2010) 11:403. doi:10.1186/gb-2010-11-9-403

157. Lien S, Koop BF, Sandve SR, Miller JR, Kent MP, Nome T, Hvidsten TR, Leong JS, Minkley $\mathrm{DR}$, Zimin A, et al. The Atlantic salmon genome provides insights into rediploidization. Nature (2016) 533:200-205. doi:10.1038/nature17164

158. Barría A, Christensen KA, Yoshida G, Jedlicki A, Leong JS, Rondeau EB, Lhorente JP, Koop BF, Davidson WS, Yáñez JM. Whole genome linkage disequilibrium and effective population size in a coho salmon (Oncorhynchus kisutch) breeding population using a high-density snp array. Front Genet (2019) 10: doi:10.3389/fgene.2019.00498

159. Kvamme BO, Skern R, Frost P, Nilsen F. Molecular characterisation of five trypsin-like peptidase transcripts from the salmon louse (Lepeophtheirus salmonis) intestine. Int J Parasitol

This article is protected by copyright. All rights reserved 
(2004) 34:823-32. doi:10.1016/j.ijpara.2004.02.004

160. Johnson S, Ewart K, Osborne J, Delage D, Ross N, Murray H. Molecular cloning of trypsin cDNAs and trypsin gene expression in the salmon louse Lepeophtheirus salmonis (Copepoda: Caligidae). Parasitol Res (2002) 88:789-796. doi:10.1007/s00436-002-0656-x

161. Bhardwaj R, Skelly PJ. Characterization of schistosome tegumental alkaline phosphatase (SmAP). PLoS Negl Trop Dis (2011) 5: doi:10.1371/journal.pntd.0001011

162. Ehsan M, Gao WX, Gadahi JA, Lu MM, Liu XC, Wang YJ, Yan RF, Xu L, Song XK, Li XR. Arginine kinase from Haemonchus contortus decreased the proliferation and increased the apoptosis of goat PBMCs in vitro. Parasites and Vectors (2017) 10:1-14. doi:10.1186/s13071017-2244-z

163. Williamson AL, Brindley PJ, Knox DP, Hotez PJ, Loukas A. Digestive proteases of bloodfeeding nematodes. Trends Parasitol (2003) 19:417-423. doi:10.1016/S1471-4922(03)00189-2

164. Chasen NM, Asady B, Lemruber L, Vommaro RC, Kissinger JC, Coppens I, Moreno SNJ. A glycosylphosphatidylinositol-achored carbonic anhyrdrase-related protein of Toxoplasma gondii is important for rhoptry biogenesis and virulence. mSphere (2017) 2:1-18.

165. Albertti LAG, Macedo AM, Chiari E, Andrews NW, Andrade LO. Role of host lysosomal associated membrane protein (LAMP) in Trypanosoma cruzi invasion and intracellular development. Microbes Infect (2010) 12:784-789. doi:10.1016/j.micinf.2010.05.015

166. Claudianos C, Dessens JT, Trueman HE, Arai M, Mendoza J, Butcher GA, Crompton T, Sinden RE. A malaria scavenger receptor-like protein essential for parasite development. $\mathrm{Mol}$ Microbiol (2002) 45:1473-1484. doi:10.1046/j.1365-2958.2002.03118.x

167. Hajnická V, Vančová-Štibrániová I, Slovák M, Kocáková P, Nuttall PA. Ixodid tick salivary gland products target host wound healing growth factors. Int J Parasitol (2011) 41:213-223. doi:10.1016/j.ijpara.2010.09.005

168. Díaz-Martín V, Manzano-Román R, Oleaga A, Encinas-Grandes A, Pérez-Sánchez R. Cloning and characterization of a plasminogen-binding enolase from the saliva of the argasid tick Ornithodoros moubata. Vet Parasitol (2013) 191:301-314. doi:10.1016/j.vetpar.2012.09.019

169. Song SM, Shin JW, de Guzman J V., Kim J, Yu HS, Jha BK, Kong HH, Hong Y, Chung D Il. Paragonimus westermani: Identification and characterization of the fasciclin I domain-

This article is protected by copyright. All rights reserved 
containing protein. Exp Parasitol (2010) 125:76-83. doi:10.1016/j.exppara.2009.12.022

170. Radulović ZM, Kim TK, Porter LM, Sze S-H, Lewis L, Mulenga A. A 24-48 h fed Amblyomma americanum tick saliva immuno-proteome. BMC Genomics (2014) 15:518. doi:10.1186/1471-2164-15-518

171. Cai G Bin, Bae YA, Kim SH, Sohn WM, Lee YS, Jiang M Sen, Kim TS, Kong Y. Vitellocytespecific expression of phospholipid hydroperoxide glutathione peroxidases in Clonorchis sinensis. Int J Parasitol (2008) 38:1613-1623. doi:10.1016/j.ijpara.2008.05.011

172. Anderson JM, Sonenshine DE, Valenzuela JG. Exploring the mialome of ticks: an annotated catalogue of midgut transcripts from the hard tick, Dermacentor variabilis (Acari: Ixodidae). BMC Genomics (2008) 9:552. doi:10.1186/1471-2164-9-552

173. Kim SH, Cai GB, Bae YA, Lee EG, Lee YS, Kong Y. Two novel phospholipid hydroperoxide glutathione peroxidase genes of Paragonimus westermani induced by oxidative stress. Parasitology (2009) 136:553-565. doi:10.1017/S0031182009005654

174. Santamaría ME, González-Cabrera J, Martínez M, Grbic V, Castañera P, Díaz L, Ortego F. Digestive proteases in bodies and faeces of the two-spotted spider mite, Tetranychus urticae. $J$ Insect Physiol (2015) 78:69-77. doi:10.1016/j.jinsphys.2015.05.002

175. Ottaviani E, Malagoli D, Grimaldi A, Eguileor M De. The immuneregulator role of neprilysin (NEP) in invertebrates. Invertebr Surviv J (2012)207-211.

176. Mulenga A, Erikson K. A snapshot of the Ixodes scapularis degradome. Gene (2011) 482:7893. doi:10.1016/j.gene.2011.04.008

177. Sakharov DVD V., Plow EFEF, Rijken DCDC. On the mechanism of the antifibrinolytic activity of plasma carboxypeptidase B. J Biol Chem (1997) 272:14477-14482. doi:10.1074/jbc.272.22.14477

178. Song JJ, Hwang I, Cho KH, Garcia M, Kim AJ, Wang TH, Lindstrom TM, Lee AT, Nishimura T, Zhao L, et al. Plasma carboxypeptidase B downregulates inflammatory responses in autoimmune arthritis. J Clin Invest (2011) 121:3517-3527. doi:10.1172/JCI46387

179. Motobu M, Tsuji N, Miyoshi T, Huang X, Islam MK, Alim M, Fujisaki K. Molecular characterization of a blood-induced serine carboxypeptidase from the ixodid tick Haemaphysalis longicornis. FEBS J (2007) 274:3299-3312. doi:10.1111/j.1742-

This article is protected by copyright. All rights reserved 
4658.2007.05852.x

180. McNair CM, Nisbet AJ, Billingsley PF, Knox DP. Molecular characterization, expression and localization of a peroxiredoxin from the sheep scab mite, Psoroptes ovis. Parasitology (2009) 136:453-460. doi:10.1017/S0031182009005538

181. Cantacessi C, Mulvenna J, Young ND, Kasny M, Horak P, Aziz A, Hofmann A, Loukas A, Gasser RB. A deep exploration of the transcriptome and "excretory/secretory" proteome of adult Fascioloides magna. Mol Cell Proteomics (2012) 11:1340-1353. doi:10.1074/mcp.M112.019844

182. Horáčková J, Rudenko N, Golovchenko M, Grubhoffer L. Der-p2 (Dermatophagoides pteronyssinus) allergen-like protein from the hard tick Ixodes ricinus - A novel member of ML (MD-2-related lipid-recognition) domain protein family. Parasitology (2010) 137:1139-1149. doi:10.1017/S0031182009992083

183. Donnelly S, O’Neill SM, Sekiya M, Mulcahy G, Dalton JP. Thioredoxin peroxidase secreted by Fasciola hepatica induces the alternative activation of macrophages. Infect Immun (2005) 73:166-173. doi:10.1128/IAI.73.1.166-173.2005

184. Figueiredo BCP, Ricci ND, de Assis NRG, de Morais SB, Fonseca CT, Oliveira SC. Kicking in the guts: Schistosoma mansoni digestive tract proteins are potential candidates for vaccine development. Front Immunol (2015) 6:1-7. doi:10.3389/fimmu.2015.00022

185. Semnani R, Nutman TB, Meng Z, Veenstra TD, Ribeiro JMC, Bennuru S. Brugia malayi Excreted/Secreted Proteins at the Host/Parasite Interface: Stage- and Gender-Specific Proteomic Profiling. PLoS Negl Trop Dis (2009) 3:e410. doi:10.1371/journal.pntd.0000410

186. Fry BG, Roelants K, Champagne DE, Scheib H, Tyndall JD, King GF, Nevalainen TJ, Norman J, Lewis RJ, Norton RS, et al. The toxicogenomic multiverse: convergent recruitment of proteins into animal venoms. Annu Rev Genomics Hum Genet (2009) 10:483-511. doi:10.1146/annurev.genom.9.081307.164356

187. Boulard C. Degradation of bovine C3 by serine proteases from parasites Hypoderma lineatum (Diptera, Oestridae). Vet Immunol Immunopathol (1989) 20:387-398. doi:10.1016/01652427(89)90083-4

188. Li Z, Zhang S, Zhang J, Liu M, Liu Z. Vitellogenin is a cidal factor capable of killing bacteria

This article is protected by copyright. All rights reserved 
via interaction with lipopolysaccharide and lipoteichoic acid. Mol Immunol (2009) 46:32323239. doi:10.1016/j.molimm.2009.08.006

189. Belley A, Chadee K. Eicosanoid production by parasites: from pathogenesis to immunomodulation? Parasitol Today (1995) 11:327-334. doi:10.1016/0169-4758(95)80185-5

This article is protected by copyright. All rights reserved 


\section{Figures}

Figure 1. Larval (chalimus) and adult stages of Lepeophtheirus salmonis and aspects of hostparasite interaction. (A) Dorsal skin of Atlantic salmon commonly infected by mobile stages of Lsal. Gravid Adult females attached posterior to the dorsal fin causing extensive erosion to the skin (annotated parasite inset). When actively feeding the gut is often filled with blood; (B) Following initial attachment on Atlantic salmon the copepodite moults into a sessile chalimus which feeds within the vicinity of the anchored filament. Host response is limited at the feeding site of the mouth tube due to louse immunomodulation. Some melanisation can be observed. The chalimus can attach to scales feeding on host mucus and epithelium (inset left) and commonly fins (micrograph) where erosion of epidermis can extend to the basal membrane but with no / limited inflammatory responses occurring around the periphery of the feeding site (micrograph - H\&E) (C-D); Secreted proteins can inhibit coagulation, prevent wound healing, facilitate digestion and immune evasion/suppression, and may be anti-microbial. For example trypsins are highly expressed in the larger more aggressive feeding adult stages $(159,160)$. (Fluorescent micrographs of in situ hybridisation (ISH)-labelled $L$ sal trypsin. Enhanced red = Trypsin expression. Enhanced autofluorescence emission was used for distinguishing anatomical structures). $\mathrm{AF}=$ Adult female, $\mathrm{CHAL}=$ Chalimus, $\mathrm{AM}=$ Adult male, dor fin $=$ dorsal fin, $\mathrm{mt}=$ mouth tube, $\mathrm{ff}=$ frontal filament, ceph $=$ cephalothorax, ant $=$ antennae, ova $=$ ovaries, gs = genital segment. Photo micrographs and ISH figures courtesy of James Bron and Jacquie Ireland, Institute of Aquaculture, University of Stirling.

Figure 2. Spectrum of susceptibility of salmonids to the salmon louse. Among species of salmonids there is a variable host response such that some species are resistant (e.g., coho, pink salmon), some are very susceptible (e.g., sockeye salmon, Atlantic salmon), while others (e.g., chinook salmon) are of medium susceptibility. This susceptibility has been demonstrated in the laboratory to be related to life history and involve a weakened inflammatory, cellular, and tissue regenerative response at the site of attachment which is strongly linked to immunomodulatory effects of the salmon louse. Associated relevant literature is shown in superscript. Figure is depicting relative susceptibility.

This article is protected by copyright. All rights reserved 
Figure 3. The host-parasite interaction between Lepeophtheirus salmonis and Atlantic salmon. Proteomic characterization of the Lsal secretome has identified at least 5 classes of proteins that facilitate the parasite evading the host immune system during feeding and attachment. Several proteins that are prominent in the secretome do not share sequence homology with known parasite virulence factors and appear to be novel to Lsal and are thus classified with "unknown" function.

This article is protected by copyright. All rights reserved 
Table 1. Protein families identified in the ES proteome of $L s a l$ showing the associated orthologous proteins orthogous to "Acari" (when available), the putative role in the host-parasite relationship, and references supporting this functional role. Protein families are grouped based on Pfam conserved domains, and the number of proteins in each family are indicated in brackets.

\begin{tabular}{|c|c|c|c|c|c|c|c|c|c|}
\hline & & & \multicolumn{6}{|c|}{ 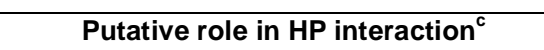 } & \multirow[b]{2}{*}{ References $^{\circ}$} \\
\hline Protein families & Example protein $^{\mathrm{a}}$ & $\begin{array}{l}\text { Orthologous } \\
\text { protein }^{\mathrm{b}}\end{array}$ & 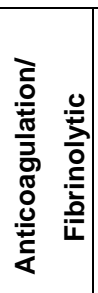 & 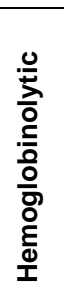 & 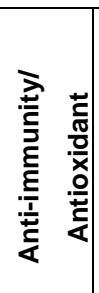 & 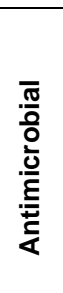 & 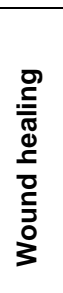 & $\begin{array}{l}5 \\
\frac{5}{0} \\
\frac{1}{2} \\
5 \\
5\end{array}$ & \\
\hline A2M (1) & Alpha-2-macroglobulin & $\begin{array}{l}\text { Alpha- } \\
\text { macroglobulin, } \\
\text { [Ixodes scapularis] }\end{array}$ & - & & & & & & $(102,117)$ \\
\hline Actin (2) & Actin & $\begin{array}{l}\text { Actin } \\
\text { [Rhipicephalus } \\
\text { microplus] }\end{array}$ & - & & & & & - & (105) \\
\hline $\begin{array}{l}\text { Alk_phosphatase } \\
\text { (1) }\end{array}$ & $\begin{array}{l}\text { Intestinal alkaline } \\
\text { phosphatase }\end{array}$ & $\begin{array}{l}\text { Alkaline } \\
\text { phosphatase-like } \\
\text { protein } 2 \\
\text { [Leptotrombidium } \\
\text { deliense] }\end{array}$ & & & - & & & & $(161)$ \\
\hline $\begin{array}{l}\text { ATP-gua_Ptrans } \\
\text { (1) }\end{array}$ & Arginine kinase & $\begin{array}{l}\text { Arginine kinase } \\
\text { [Haemonchus } \\
\text { contortus] }\end{array}$ & & & - & & & & (162) \\
\hline Peptidase_A1 (1) & Cathepsin D & $\begin{array}{l}\text { Cathepsin D2 } \\
\text { [lxodes ricinus] }\end{array}$ & & $\bullet$ & & & & & $(119,163)$ \\
\hline Astacin (3) & $\begin{array}{l}\text { Zinc metalloproteinase } \\
\text { nas-4 }\end{array}$ & $\begin{array}{l}\text { Astacin-like } \\
\text { metalloprotease } \\
\text { toxin } 5 \\
\text { [Galendromus } \\
\text { occidentalis] }\end{array}$ & & & - & & - & & $(119,163)$ \\
\hline $\begin{array}{l}\text { Carb_anhydrase } \\
\text { (1) }\end{array}$ & Carbonic anhydrase 2 & $\begin{array}{l}\text { Carbonic } \\
\text { anhydrase [/xodes } \\
\text { scapularis] }\end{array}$ & & & & & & - & (164) \\
\hline CD36 (1) & $\begin{array}{l}\text { Scavenger receptor } \\
\text { class B }\end{array}$ & $\begin{array}{l}\text { Lysosome } \\
\text { membrane protein } \\
\text { 2-like protein } \\
\text { [Dinothrombium } \\
\text { tinctorium] }\end{array}$ & & & - & & & - & $(165,166)$ \\
\hline
\end{tabular}

This article is protected by copyright. All rights reserved 


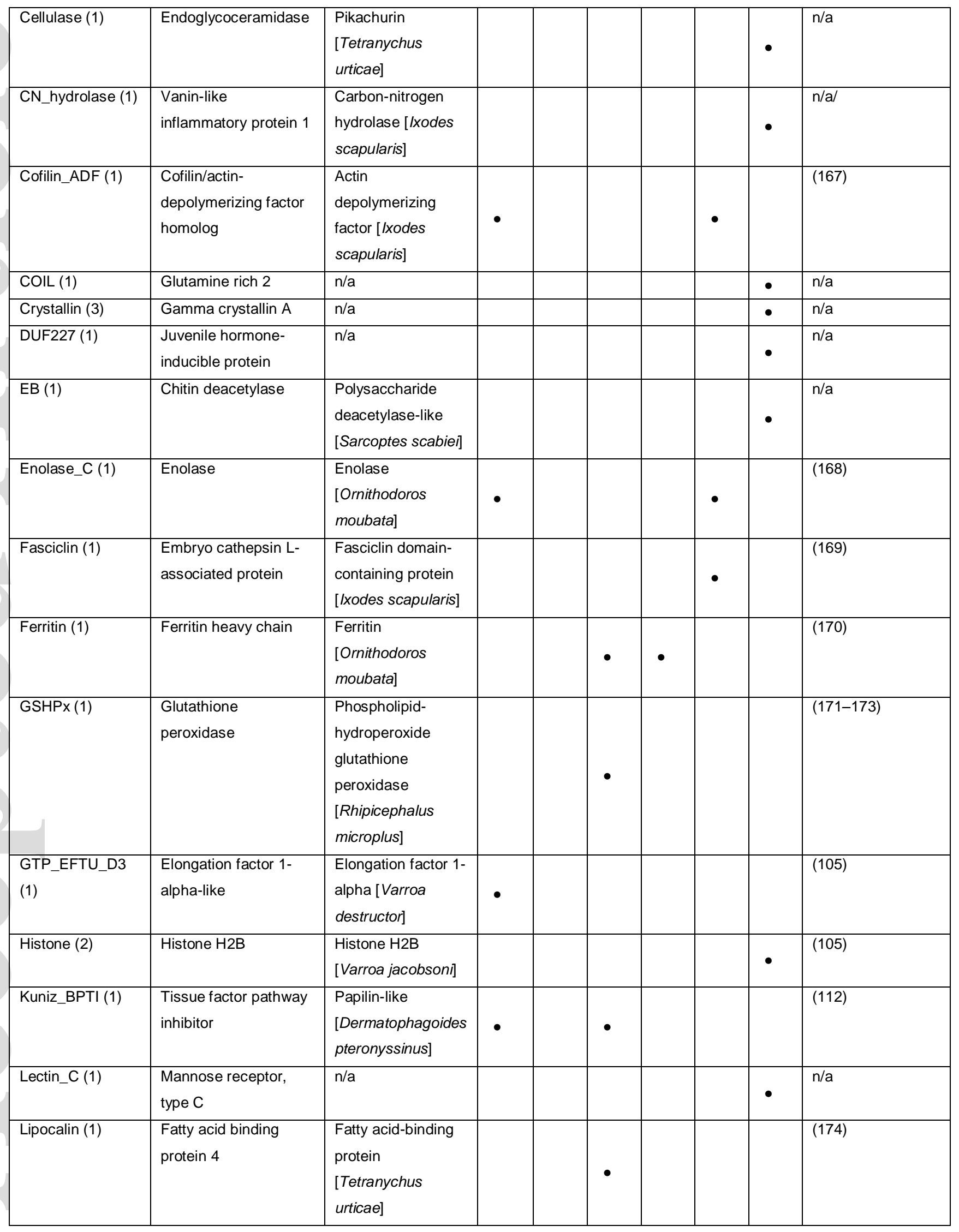

This article is protected by copyright. All rights reserved 


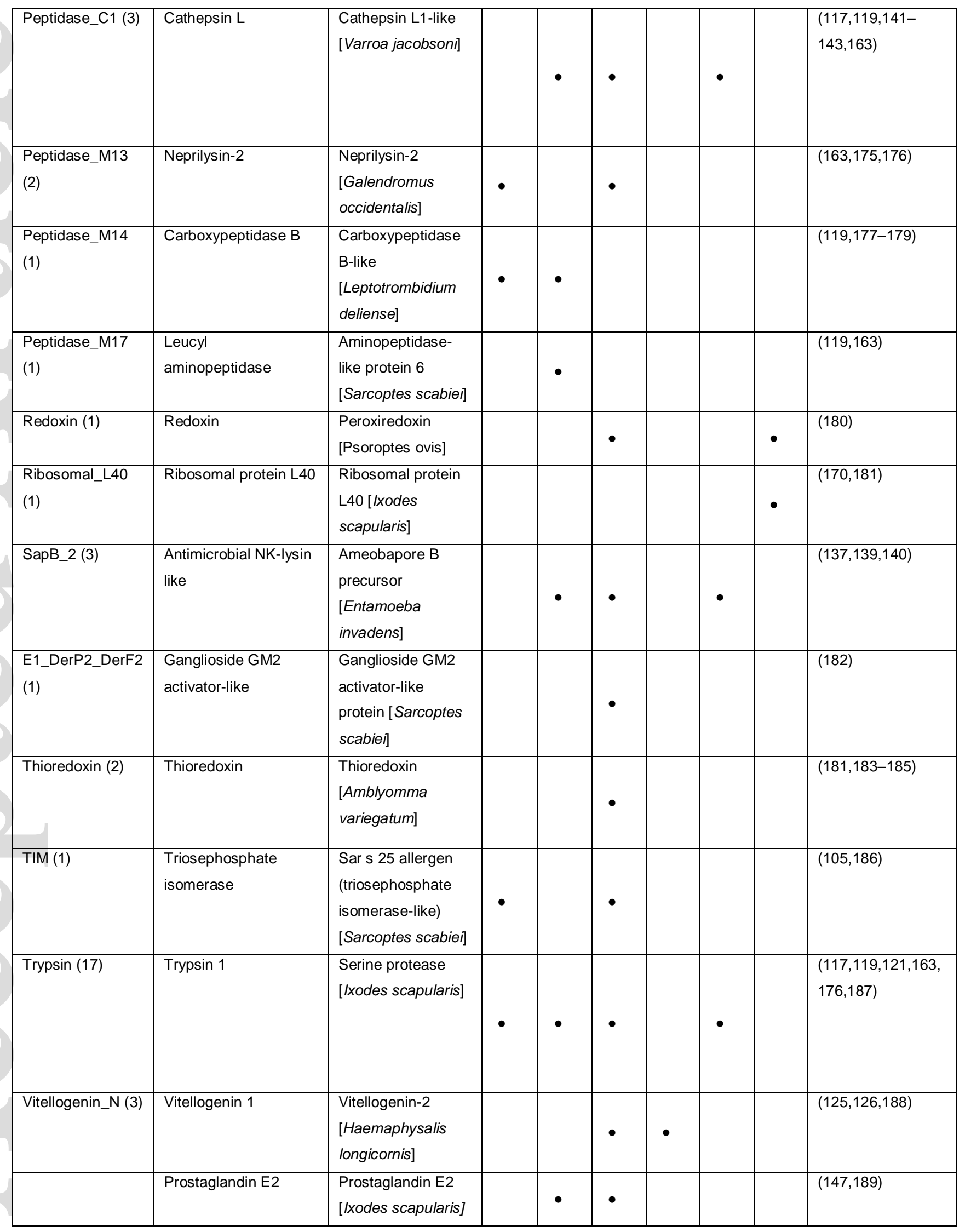

This article is protected by copyright. All rights reserved 
${ }^{\mathrm{a}}$ An example protein is given when there are multiple proteins present within the same family

${ }^{\mathrm{b}}$ Orthologous proteins in other ectoparasites were determined using sequence homology with an e-value cutoff of $10^{-5}$

${ }^{\mathrm{c}}$ The role of $L$. salmonis proteins in the host-parasite interaction were inferred by homology to orthologues in other parasite systems

${ }^{\mathrm{d}}$ References pertaining to the inferred function are given

This article is protected by copyright. All rights reserved 

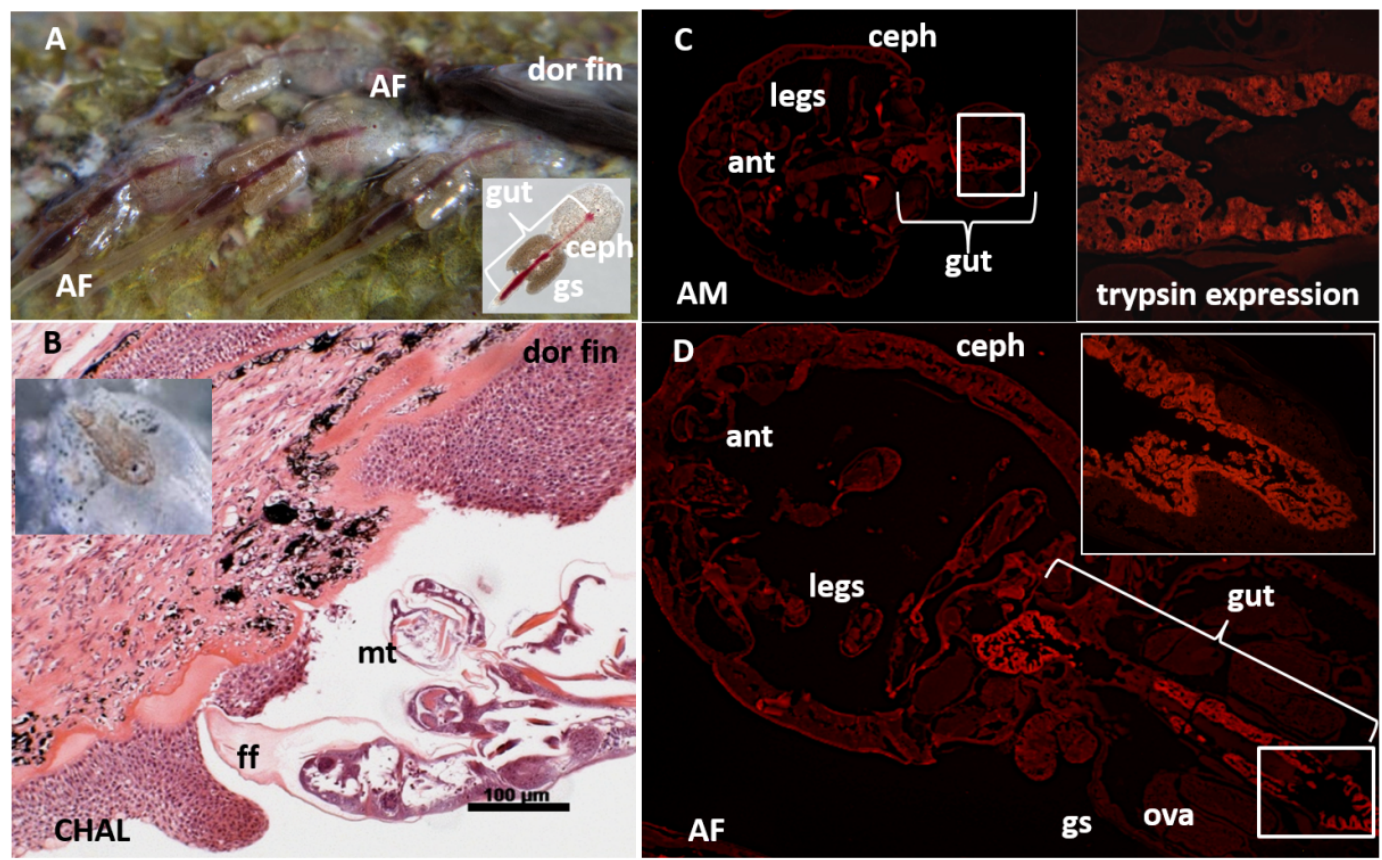

pim_12731_f1.tif

This article is protected by copyright. All rights reserved 


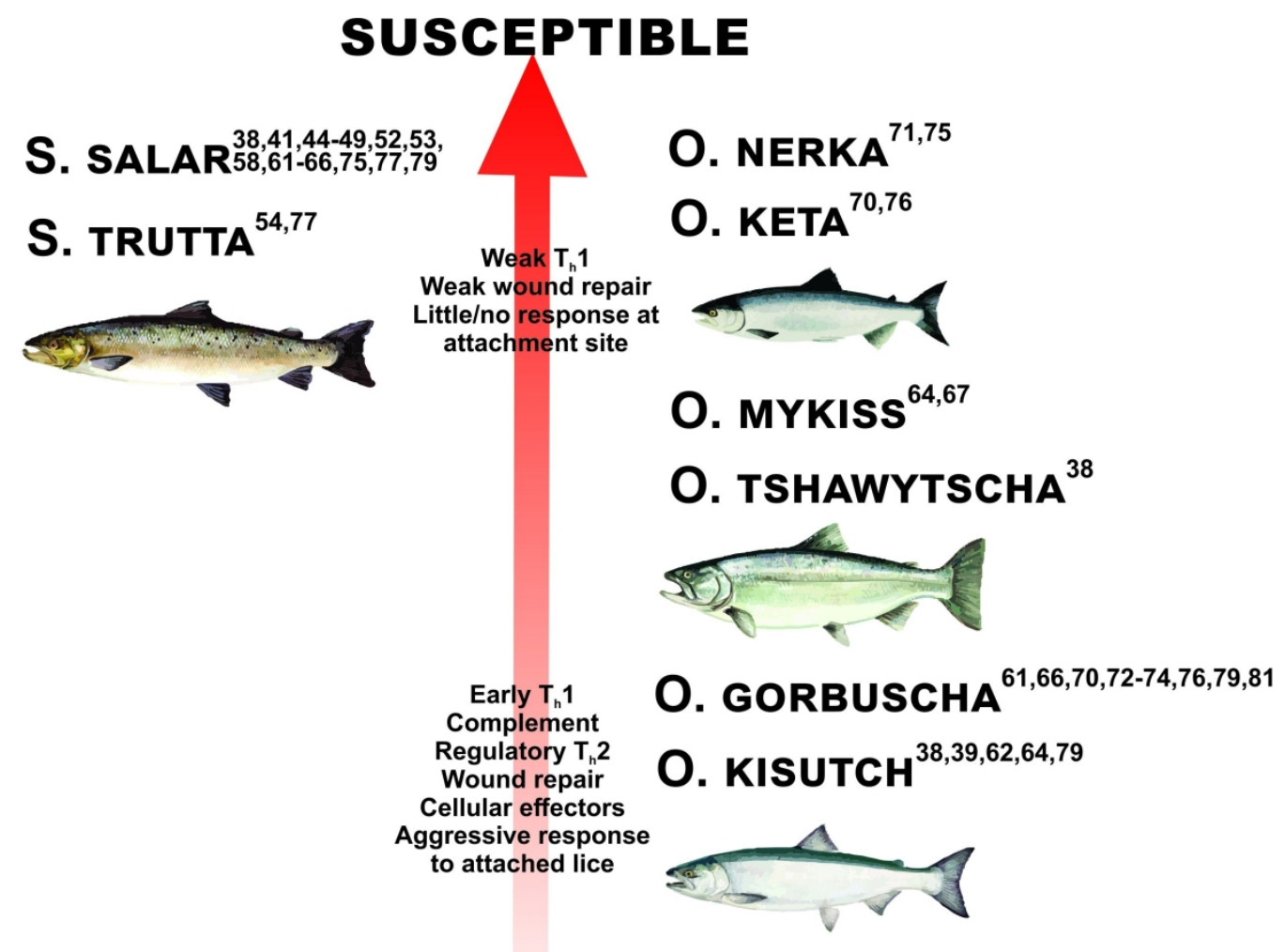

RESISTANT

pim_12731_f2.jpg

This article is protected by copyright. All rights reserved 


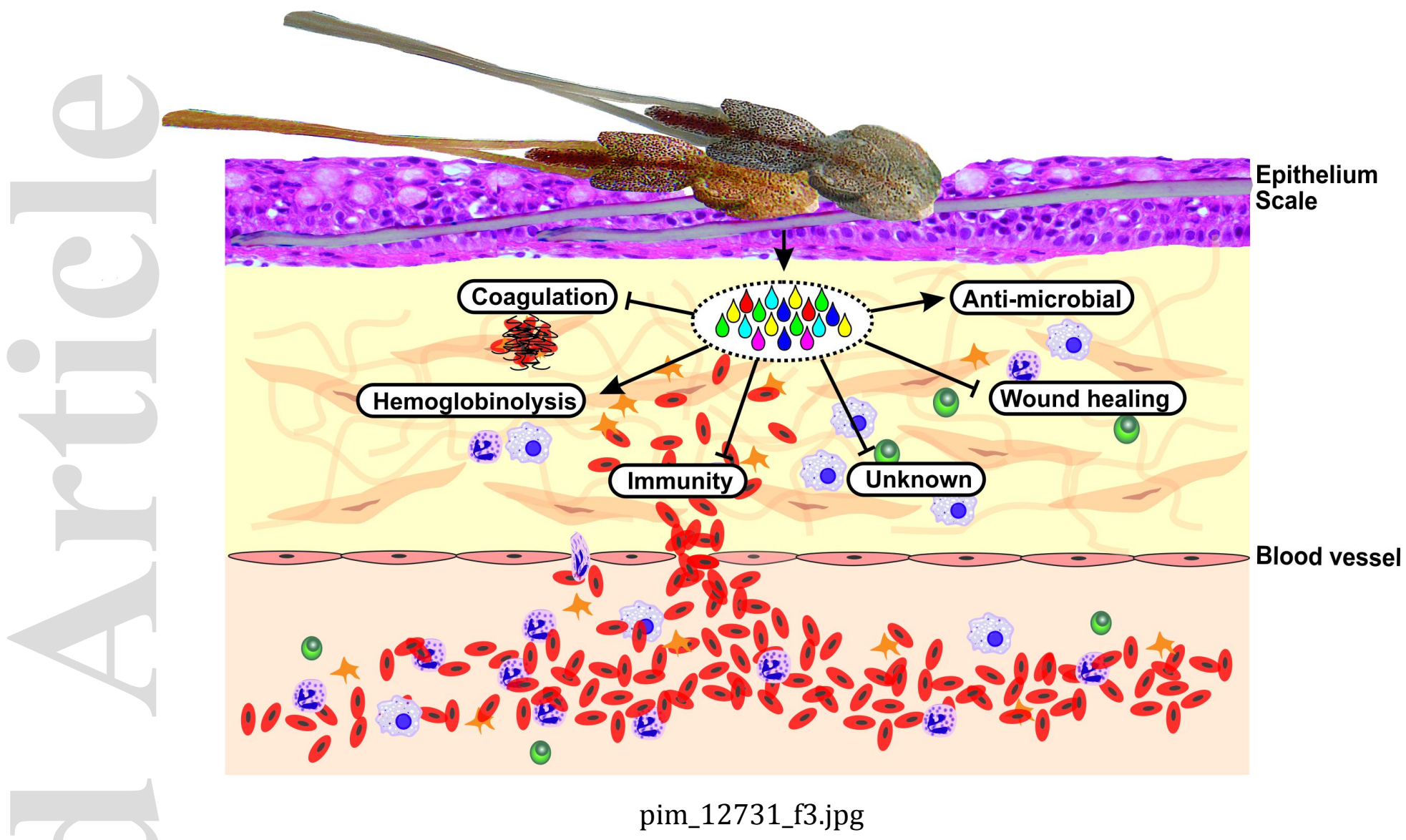

This article is protected by copyright. All rights reserved 